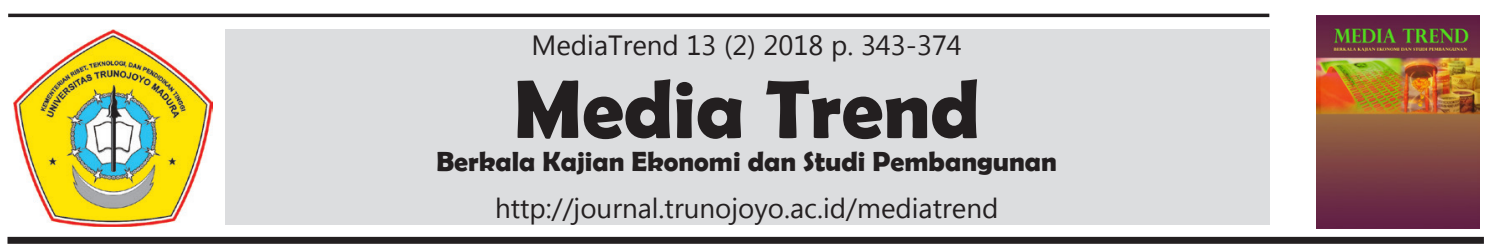

\title{
Perubahan Landscape Ekonomi Wilayah (Studi Kasus Pendekatan Historical Input-Output Di Jawa Timur)
}

\author{
Muhammad Alwan Habibi Mushlih ${ }^{1^{*}}$, Teguh Hadi P ${ }^{2}$, Fajar Wahyu $\mathbf{P}^{3}$ \\ 1,2,3 Jurusan Ilmu Ekonomi dan Studi Pembangunan, Fakultas Ekonomi dan Bisnis, Universitas Jember
}

\section{Informasi Artikel \\ Sejarah artikel: \\ Diterima September 2018 \\ Disetujui Oktober 2018 \\ Dipublikasikan Oktober 2018}

\section{Keywords:}

Structural Changes,

Input-Output,

Multipler Product Matrix

\begin{abstract}
A B S TR ACT
Industrialization grew fast in East Java after 1998 crisis and can be look at the first position of the easy of doing business category year 2017 by the Asia Competiveness Institute. This study aims to determine the pattern of economic landscape in East Java by using the input-output table which is then analyzed into various tables derived from the input-output itself. Structural changes occurred in East Java during the period 2000 to 2015 which is shown by changes in economic landscape. This change can be seen in the Multiplier Product Matrix (MPM). In 2000 the highest MPM value was in 2000 the highest MPM value was mining and quarrying sector with other industrial sector with MPM value equal to 0,1247. In 2006 the highest MPM value is fishery sector with trade sector with MPM value equal to 0,11012. In 2010 the highest MPM value of the livestock sector with the sector of financial institutions, building businesses, and services companies with MPM value of 0.141735. In 2015 the highest MPM value is the mining and quarrying sector with other industrial sectors with MPM value of 0.19426 .
\end{abstract}




\section{Pendahuluan}

Indonesia dalam kurun 30 tahun terakhir telah mengalami transformasi struktural ekonomi yang masif. Parameter yang digunakan oleh Asian Deevelopment Bank (ADB) dalam melihat perubahan struktural yang ada pada suatu negara adalah sumbangsih tiga sektor utama terhadap PDB. Dilihat dari PDB Indonesia, kontribusi sektor primer terus mengalami penurunan dan sektor tersier menjadi dominasi perekonomian Indonesia (Siswanto, 2010).

Jawa Timur sebagai salah satu wilayah utama di Indonesia juga mengalami transformasi struktural yang selaras dengan yang terjadi di nasional. Badan Pusat Statistik mencatat pada tahun 2015 Jawa Timur mampu memberikan kontribusi PDRB terhadap PDB nasional diurutan kedua, naik satu level dibandingkan periode sebelumnya, yaitu tahun 2010 berada pada urutan ketiga. Selama 13 tahun terakhir, terjadi perubahan komposisi kontribusi, jika dilihat dari tiga sektor utama terhadap PDRB Jawa Timur dengan melihat PDRB Jawa Timur menggunakan harga konstan tahun 2000. yang selaras dengan sektor primer. Sektor sekunder mengalami penurunan selama periode tersebut. Perubahan share yang terjadi akan memberikan implikasi terhadap perubahan permintaan tenaga kerja yang dibutuhkan.

Dominasi sektor tersier pada perekonomian Jawa Timur mengindikasikan adanya perubahan struktur perekonomian di Jawa Timur. Perubahan struktur perekonomian Jawa Timur bisa diakibatkan dari dua faktor utama, yaitu faktor domestik dan faktor internasional.

Dilihat dari faktor domestik, terjadinya perubahan struktur perekonomian di Jawa Timur diakibatkan sebagai respon dari kebijakan yang terjadi dalam skala nasional terhadap daerah-daerah yang ada di wilayahnya.

Tahun 1998 adalah tahun yang paling memberikan kesan buruk terhadap performa perekonomian Indonesia (Bank Dunia, 2011). Pada tahun ini terjadi krisis meneter yang mengguncang ekonomi Indonesia yang membawa dampak yang besar terhadap Indonesia.

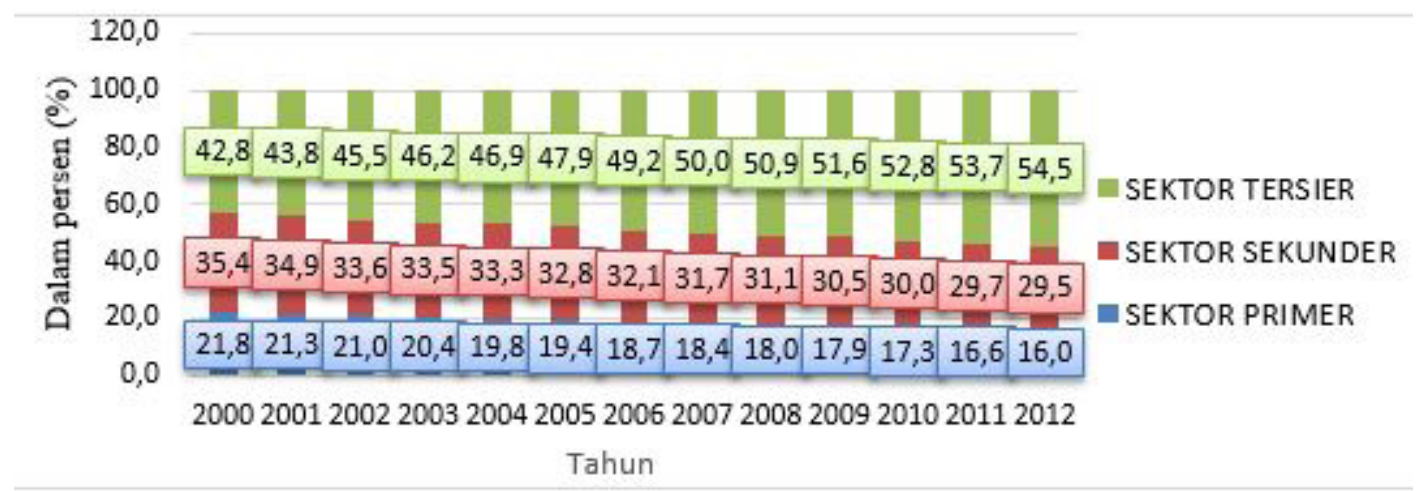

\section{Gambar 1}

Kontribusi 3 Sektor Utama Terhadap PDRB Jawa Timur Tahun Konstan 2000

Kontribusi sektor tersier telah mendominasi aktivitas ekonomi Jawa Timur, menggeser sektor-sektor lainnya. Selama tahun 2000 sampai tahun 2012, share sektor primer terus mengalami penurunan. Sektor sekunder memiliki pola
Krisis ini tidak hanya melanda Indonesia, akan tetapi negara di Asia seperti Malaysia, Singapura, Korea Selatan, dan Thailand (Yustika, 2012). Dimulai dari adanya contagion effect dari penurunan mata uang Bath, Thailand yang 
pada akhirnya membawa dampak terhadap nilai tukar rupiah (Tambunan, 2010) dan pada saat yang bersamaan utang swasta tehadap luar negeri jatuh tempo dan terjadi capital outflow dari Indonesia (Ratna, 2017); (Raz, et al. 2012).

Dilihat dari kontribusi tiga sektor utama terhadap PDB Indonesia, pada saat sebelum krisis perekonomian Indonesia ditopang oleh sektor sekunder, dan pada saat krisis yang menopang adalah sektor primer.

Dominasi sektor primer pada saat terjadi krisis 1998 tidak pula menunjukkan performa yang bagus mengingat nilai ekspor sektor primer mengalami penurunan (Barichello, 1998). Setelah krisis, sektor tersier menjadi dominasi perekonomian Indonesia (Yudanto dan Santoso, 1998).

Di Indonesia, penyelesaian krisis 1998 dilakukan melalui campur tangan International Monetary Fund (IMF) (Karmeli dan Fatimah, 2008). Penyelesaian yang dilakukan adalah dengan melakukan restrukturisasi berbagai sektor, seperti sektor perbankan dan keuangan, sektor riil, dan sektor kelembagaan. Saran dari IMF tidak hanya dilakukan dalam satu periode dalam satu kali nota kesepahaman, akan tetapi dilakukan beberapa kali penandatangan kesepahaman antara Indonesia dengan IMF dalam penanggulangan krisis. Yang menarik adalah dalam setiap kali pemberian saran, IMF selalu menekankan pada perubahan struktural perekonomian. Pada 31 Oktober 1997 reformasi yang direkomendasikan pada poin kelima adalah penyesuaian struktural, dilanjutkan pada 15 Januari 1998 reformasi struktural dan swastanisasi juga menjadi rekomendasi IMF (Tarmidi, 1999); (Nematnejad, 2000).

Implikasi yang diterima dari kebijakan ini adalah adanya penilain yang di lakukan oleh Asia Competitivness Institute $(\mathrm{ACl})$ mengenai kemudahan berbisnis di Indonesia, yang artinya adanya kelonggaran terhadap sektor swasta. Pada November 2017, Jawa Timur menduduki peringkat pertama kategori Easy of Do- ing Business (EDB) atau tingkat kemudahan berbisnis di Indonesia, naik 2 level dibandingkan periode sebelumnya, yakni pada tahun 2015 menduduki peringkat 3 . Dengan demikian, tingkat liberalisasi yang terjadi di Jawa Timur sangat mendominasi perekonomian Indonesia yang tercermin dalam EDB Jawa Timur.

Faktor internasional yang mempengaruhi perubahan struktur perekonomian wilayah adalah kebijakan yang diambil oleh suatu negara berhubungan dengan internasional. Menurut Kuznet (dalam Jhingan, 2003;64) pertumbuhan modern dan perubahan struktural suatu negara akan dipengaruhi hubungan negara tersebut dengan negara lain. Bank dunia memberikan ukuran terhadap hubungan internasional suatu negara melalui degree of openness atau derajat keterbukaan negara.

Secara teoritis, pertumbuhan ekonomi melibatkan perubahan struktur perekonomian suatu negara (Amir dan Nazara, 2005) disamping faktor yang dipaparkan diatas. Perubahan struktur yang terjadi pada suatu daerah tercermin dalam keterkaitan antar sektor ekonomi (Tajerin, 2008) baik keterkaitan kedepan maupun keterkaitan kebelakang (Nassif, Feijo, dan Araujo, 2013) yang di visualisasikan kedalam bentuk Multiplier Product Matrix (MPM) (Borges and Montibeler, 2014); (Szirmai, 2012). MPM akan memberikan gambaran aktivitas perekoniman yang terjadi pada suatu wilayah (Sonis dan Hewings, 1999); (D'Hernoncourt, Cordier, and Hadley, 2011) didapat dari perhitungan keterkaitan langsung tidak langsung dari tabel input-output yang ada pada suatu wilayah. (Guilhoto, Sonis, and Hewings, 1999); (Taylor and Rada, 2006). Perubahan struktur ekonomi akan memberikan dampak pula terhadap perpindahan tenaga kerja dari sektor yang memiliki produktivitas rendah kepada sektor yang memiliki produktivitas tinggi serta meningkatkan produktivas tenaga kerja tersebut (Rodrik, 2013) yang ditandai dengan meningkatnya 
kontrinbusi sektor tersier hingga $70 \%$ terhadap PDB (Szirman, 2012).

Berdasarkan uraian di atas, maka rumusan masalah dalam penelitian ini adalah bagaimana pattern of economic landscape di Jawa Timur sesudah krisis ekonomi 1998?.

Kemudian tujuan yang ingin dicapai dari penelitian ini adalah untuk mengetahui apakah belanja daerah berpengaruh terhadap PDRB di Kabupaten Jember, untuk mengetahui apakah ivestasi berpengaruh terhadap PDRB di Kabupaten Jember, untuk mengetahui apakah tingkat partisipsi angkatan kerja berpengaruh positif terhadap PDRB di Kabupaten Jember

\section{Metode \\ Jenis Penelitian}

Penelitian ini menggunakan pendekatan deskriptif kuantitatif. Pendekatan kuantitatif yang dilakukan adalah dalam penghitungan secara matematis. Penelitian ini mengkaji lebih dalam fenomena sesudah krisis 1998 terhadap perubahan struktur Jawa Timur.

Jenis penelitian ini merupakan penelitian deskriptif kuantitatif. Pendekatan deskriptif digunakan untuk memberi gambaran tentang transformasi struktural yang terjadi selama periode tahun 2000 hingga tahun 2015 di Jawa Timur. Pendekatan kuantitaf digunakan untuk mengukur seberapa besar perubahan tersebut dan bagaimana dampaknya pada perekonomian Jawa Timur.

\section{Jenis dan Sumber Data}

Data yang digunakan dalam penelitian ini adalah data sekunder dengan sumber Badan Pusat Statistik Jawa Timur, berupa Tabel Transaksi Total Atas Harga Produsen dari Tabel Input-Output Jawa Timur Tahun 2000, 2006, 2010, 2016 yang diagregasikan menjadi 19 sektor. Harga produsen merupakan harga yang dibayarkan kepada produsen barang/jasa tersebut pada semua transaksi barang/jasa baik impor maupun domestik (Amir dan Nazara, 2005).

\section{Populasi dan Sampel}

Penelitian ini menggunakan teknik purposive sampling, yaitu periode tahun 2000, 2006, 2010, dan 2015 dengan mempertimbangkan pada tahun tersebut terdapat kondisi setelah krisis 1998 yang terjadi di Indonesia dan diduga berpengaruh secara signifikan terhadap perubahan perekonomian Jawa Timur.

\section{Metode Analisis Data Input-Output}

Tabel input-output merupakan sebuah matriks yang berisi informasi data statistik yang menggambarkan transaksi barang dan jasa antar suatu sektor ekonomi dan keterkaitannya dengan sektor ekonomi lain dalam kurun waktu tertentu (BPS Jatim, $2016: 5$ ).

Berikut merupakan kerangka dasar Tabel I-O Jawa Timur yang dipublikasikan oleh BPS Jawa Timur.

Tabel 1

Kerangka Dasar Tabe I-O Jawa Timur

\begin{tabular}{|c|c|c|c|}
\hline \multirow{3}{*}{ Susunan } & \multicolumn{2}{|c|}{ PERMINTAAN } & \multirow{3}{*}{ PENYEDIAAN } \\
\hline & Permintaan & \multirow{2}{*}{ Permintaan Akhir } & \\
\hline & Sektor Produksi & & \\
\hline Input Antara & I & I & \\
\hline Input Primer & III & & \\
\hline
\end{tabular}

Sumber : BPS Jatim, diolah 
Dari tabel input-output Jawa Timur yang sudah dipublikasikan oleh BPS Jawa Timur, ada beberapa tahapan yang akan dilakukan untuk menganalisis data tersebut, yaitu :

\section{Agregasi Sektor}

Di dalam masing-masing Tabel I-O Jawa Timur, terdapat pengklasifikasian dalam sejumlah sektor. Tabel I-O Jawa Timur Tahun 2000 diklasifikasikan menjadi 66 sektor dengan matrik $66 \times 66$, Tabel I-O Jawa Timur Tahun 2006, 2010, 2015 diklasifikasikan menjadi 110 sektor dengan matrik $110 \times 110$. Dalam penelitian ini, sektor-sektor tersebut akan diagregasi menjadi 19 sektor, sebagaimana terlihat pada tabel berikut : dimana $a_{i j}$ adalah koefisien input sektor i oleh sektor ke $j, x_{i j}$ adalah penggunaan input sektor i oleh sektor ke $j, X_{j}$ adalah output sektor ke $j$.

Pada perhitungan koefisien input dalam penelitian ini, hanya menggunakan analisis model input-output terbuka.

3. Menyusun Matriks Identitas

Matriks identitas merupakan matriks yang disusun berdasarkan banyaknya sektor yang ada pada table input-output (Tanaka) dengan angka 1 pada tiap perkalian sektor itu sendiri dan angka 0 di matriks yang lain.

$$
\left[\begin{array}{cccc}
1 & 0 & \cdots & 0 \\
0 & 1 & \cdots & 0 \\
\cdots & \cdots & \cdots & \cdots \\
0 & 0 & \cdots & 1
\end{array}\right]
$$

Tabel 2

Klasifikasi 19 Sektor Tabel Input-Output

\begin{tabular}{cl}
\hline Sektor & \multicolumn{1}{c}{ Keterangan } \\
\hline 1 & Padi \\
2 & Tanaman Bahan makanan \\
3 & Tanaman Pertanian Lainnya \\
4 & Peternakan dan hasil-hasilnya \\
5 & Kehutanan \\
6 & Perikanan \\
7 & Pertambangan dan Penggalian \\
8 & Industri makanan, minuman, dan tembakau \\
9 & Industri lainnya \\
10 & Pengilangan minyak bumi \\
11 & Listrik, Gas. Dan Air Minum \\
12 & Bangunan/Kontruksi \\
13 & Perdagangan \\
14 & Restoran dan Hotel \\
15 & Pengangkutan dan Komunikasi \\
16 & Lembaga Keuangan, Usaha bangunan, dan jasa perusahaan \\
17 & Pemerintahan umum dan pertahanan \\
18 & Jasa-Jasa \\
19 & Kegiatan yang tidak jelas batasannya \\
\hline
\end{tabular}

Sumber : BPS Jatim, diolah

2. Menghitung Koefisien Input

Koefisien input merupakan koefisien yang mengggambarkan komposisi input antara yang digunakan pada masing-masing sektor (Leontif, 1986:22). Rumus koefisien teknologi adalah sebagai berikut :

$$
a_{i j}=\frac{x_{i j}}{X_{j}}
$$

4. Menyusun Matriks Leontif

Matriks leontif merupakan matriks yang disusun berdasarkan pengurungan antara matriks identitas dengan matriks koefisien input (Sargento, 2009)

$$
\mathrm{M}_{\mathrm{L}}=[I-A]
$$


dimana adalah $\mathrm{M}_{\perp}$ adalah Matriks leontif, I adalah Matriks identitas, $A$ adalah Matriks koefisien input.

Pada perhitungan matriks leontif dalam penelitian ini, hanya menggunakan analisis model input-output terbuka.

\section{Menyusun Matriks Leontif Kebalikan}

$$
\mathrm{M}_{0}=[I-A]^{-1}
$$

dimana adalah $M_{L}$ adalah Matriks leontif kebalikan, I adalah Matriks identitas, $A$ adalah Matriks koefisien input.

Pada perhitungan matriks leontif kebalikan dalam penelitian ini, hanya menggunakan analisis model input-output terbuka.

\section{Menghitung Keterkaitan Langsung}

Keterkaitan langsung dalam hal ini, dibedakan atas keterkaitan kebelakang langsung dan keterkaitan kedepan langsung. Keterkaitan kebelakang langsung menunjukkan efek dari suatu sektor terhadap tingkat produksi sektor sebagai penyedia input bagi sektor tersebut secara langsung dan dapat dihitung secara matematis sebagai berikut :

$$
B(d)_{j}=\sum_{i=1}^{n} \propto_{i j}
$$

Keterkaitan ke depan langsung menunjukkan banyaknya output dari suatu sektor yang telah dipakai oleh sektor lain dengan formulasi rumus sebagai berikut:

$$
F(d)_{j}=\sum_{j=1}^{n} \bar{a}_{i j}
$$

Pada perhitungan keterkaitan langsung dalam penelitian ini, hanya menggunakan analisis model input-output terbuka.
7. Menghitung Keterkaitan Langsung Tidak Langsung

Keterkaitan langsung tidak langsung dalam hal ini, dibedakan atas keterkaitan kebelakang langsung tidak langsung dan keterkaitan kedepan langsung tidak langsung. Keterkaitan kebelakang langsung tidak langsung dirumuskan sebagai berikut :

$$
\operatorname{IK} B_{j}=\frac{\sum_{i=1}^{n} b_{i j}}{\sum_{i=1}^{n} \sum_{j=1}^{n} b_{i j}} n
$$

dimana IKB adalah Indeks keterkaitan langsung tidak langsung kebelakang sektor $j, b_{i j}$ adalah unsur matriks kebalikan Leontif baris $i$ dan kolom $j, n$ adalah ukuran matriks leontif (ukuran sektoral table IO).

Keterkaitan kedepan langsung tidak langsung dirumuskan sebagai berikut :

$$
I K D_{i}=\frac{\sum_{j=1}^{n} b_{i j}}{\sum_{i=1}^{n} \sum_{j-1}^{n} b_{i j}} n
$$

$I K D_{i j}$ adalah Indeks keterkaitan langsung tidak langsung kebelakang sektor $i$, $b_{i j}$ adalah unsur matriks kebalikan Leontif baris $i$ dan kolom $j, n$ adalah ukuran matriks leontif (ukuran sektoral table IO).

Pada perhitungan keterkaitan langsung tidak langsung dalam penelitian ini, hanya menggunakan analisis model inputoutput terbuka.

\section{Menghitung Multiplier Product Matrix}

Untuk melihat terjadinya perubahan struktur perekonomian digunakan Multiplier Poduct Matrix (MPM) (Nassif, Feijo, dan Araujo, 2013); (D'Hernoncourt, Cordier, dan Hadley, 2011). MPM menyediakan suatu ukuran interaksi sektor-sektor dalam perekonomian yang menyajikan pengaruh suatu sektor terhadap sektor-sektor lainnya. Besaran pengaruhnya dapat di perbandingkan dengan sektor lainnya atau sektor itu sendiri untuk waktu yang ber- 
beda. Secara matematis, nilai MPM (Sonis dan Hewings, 1999) diperoleh dengan formulasi :

$$
M P M=\frac{1}{V}\left\|b_{i} \cdot b_{\cdot j}\right\|^{*}=\frac{1}{V}\left(\begin{array}{c}
b_{1} \\
b_{2} \\
\vdots \\
b_{n}
\end{array}\right)\left(b_{\cdot 1} b_{2} \cdots b_{n}\right)
$$

dimana MPM adalah Multiplier Product Matrix, $V$ adalah jumlah semua komponen didalam matriks kebalikan leontif, $b_{(i \cdot)}$ adalah jumlah semua kolom dalam baris ke $i$ dari matriks invers leontif, $b_{(j)}$ adalah jumlah semua kolom dalam kolom ke $j$ dari matriks invers leontif.

Pada perhitungan MPM dalam penelitian ini, hanya menggunakan analisis model input-output terbuka.

9. Menghitung Dampak Permintaan Akhir Terhadap Output

Dampak permintaan akhir terhadap output di dapat dari perkalian matriks leontif invers dengan kuadran 2 tabel input-output, dapat diformulasikan sebagai berikut:

$$
D F=(I-A)^{-1} F
$$

dimana DF adalah Dampak permintaan akhir terhadap output, (I-A)-1 adalah Matriks leontif inverse, $\mathrm{F}$ adalah Kuadran 2 tabel input-output.

Pada perhitungan dampak permintaan akhir terhadap output dalam penelitian ini, hanya menggunakan analisis model input-output terbuka.

10. Menyusun Matriks Nilai Tambah Bruto

Sebelum matriks disusun, yang pertama harus dilakukan adalah mencari nilai tambah bruto pada masing-masing sektor, secara matematis dapat dirumuskan sebagai berikut :

$$
v_{j}=\frac{V A_{j}}{X_{j}}
$$

dimana $v_{j}$ adalah Koefisien nilai tambah bruto, $V A_{j}$ adalah Total kuadran 3 untuk sektor $j, X_{j}$ adalah Total kuadram 1 dan 3 untuk sektor $j$.

Setelah nilai tambah bruto ketahui, selanjutnya adalah disusun dalam sebuah matriks dengan ketentuan sebagai berikut :

$$
\hat{v}=\left[\begin{array}{cccc}
v_{1} & 0 & \cdots & 0 \\
0 & v_{2} & \cdots & 0 \\
\cdots & \cdots & \cdots & \cdots \\
0 & 0 & \cdots & v_{n}
\end{array}\right]
$$

Pada perhitungan koefisien nilai tambah bruto dalam penelitian ini, hanya menggunakan analisis model input-output terbuka.

11. Menghitung Dampak Permintaan Akhir Terhadap Nilai Tambah Bruto

Untuk menghitung dampak permintaan akhir terhadap nilai tambah bruto, digunakan formulasi sebagai berikut :

$$
V A=\hat{V}(I-A)^{-1} F
$$

dimana VA adalah Dampak permintaan akhir terhadap nilai tambah bruto, $V^{(}(I-A)^{-1}$ adalah Pengganda nilai tambah bruto, $F$ adalah Stimulus.

Pada perhitungan dampak permintaan akhir terhadap nilai tambah bruto dalam penelitian ini, hanya menggunakan analisis model input-output terbuka.

\section{Hasil dan Pembahasan}

A.Tahap Agregasi Sektor Tabel InputOutput Provinsi Jawa Timur Tahun 2000 Sampai Tahun 2015 Klasifikasi 19 Sektor

Tahap agregasi yang dilakukan berdasarkan tabel input-output yang disusun oleh BPS Provinsi Jawa Timur. Tahun 2000 terdapat 100 sektor dengan matriks input-output $100 \times 100$, Tahun 2006, 2010, dan 2015 tabel input-output di klasifikasikan menjadi 110 sektor dengan matriks $110 \times 110$. Proses agregasi klasifi- 
kasi 19 sektor, terdiri dari sektor 01 dengan keterangan kode padi, berisikan satu komoditas saja yakni padi dengan kode 01 . Sektor 02 pada klasifikasi 19 sektor adalah sektor tanaman bahan makanan makanan, terdiri dari komoditas jagung dengan kode 02 , ketela pohon dengan kode 03 , kedelai dengan kode 04, sayur-sayuran dengan kode 05, buah-buahan dengan kode 06, dan kode 07 dengan keterangan tanaman bahan makanan lainnya. Selanjutnya klasifika sektor 03 pada agregasi 19 sektor adalah tanaman pertanian lainnya yang terdiri atas tebu dengan kode 08, kelapa dengan kode 09, cengkeh dengan kode 10, tembakau dengan kode 11, dan kode 12 yakni kopi, serta kode 13 yakni tanaman perkebunan lainnya. Klasifikasi 19 sektor yang keempat adalah sektor peternakan dan hasil-hasilnya yang terdiri dari kode 14 peternakan sapi potong, kode 15 peternakan lainnya, kode 16 peternakan hewan perah, kode 17 pemotongan hewan, dan kode 18 unggas dan hasil-hasilnya. Sektor 05 pada klasifikasi 19 sektor adalah sektor kehutanan, hanya terdiri dari kode 19 yakni kehutanan dan perburuan. Klasifikasi sektor 06 sektor pada agregasi 19 sektor adalah sektor perikanan yang terdiri dari perikanan laut dan hasil laut lainnya dengan kode 20 , kode 21 yakni perikanan darat dan hasil perikanan darat lainnya, dank ode 22 pengeringan dan penggaraman ikan. Sektor 07 adalah sektor pertambangan dan penggalian yang terdiri dari kode 35 minyak bumi, kode 46 gas bumi, kode 37 belerang, dan kode 38 penggalian. Pada klasifikasi 19 sektor, sektor ke 08 adalah sektor industri makanan, minuman, dan tembakau yang terdiri dari kode 39 industri pengolahan dan pengawetan daging, susu, sayur, dan buah-buahan, kode 40 industri minyak dan lemak, kode 41 industri penggilingan padi-padian, kode 42 industri tepung segala jenis, kode 43 industri makanan dari tepung, kode 44 industri gula, industri makanan lainnya dengan kode 45 , kode 46 industri makanan hewan, kode 47 indutri minuman, kode 48 industri rokok, dan kode 49 industri tembakau. Selanjutnya sektor ke 09 pada klasifikasi 19 sektor adalah sektor industry lainnya yang terdiri dari kode 50 industri tekstil dan pakaian jadi, kode 51 industri pengolahan dan penyamakan barang dari kulit, kode 52 industri bambu, kayu, dan rotan, kode 53 industri kertas, barang-barang dari kertas dan karton, kode 54 industri pupuk dan pestisida, kode 55 industri obat-obatan dan jamu, kode 56 industri kimia lainnya, kode 58 industri bahan karet dan plastik, kode 59 industri barang dari mineral bukan logam, kode 60 industri semen dan kapur, kode 61 industri logam dasar, kode 62 industri logam dasar, kode 63 industri mesin, kode 64 industri barang-barang elektronika, kode 65 industri alat pengangkutan dan perbaikan kecuali kapal, kode 66 industri kapal dan perbaikannya, dan k ode 67 industri barang yang tidak digolongkan dimana-mana. Sektor 10 pada agregasi ini adalah sektor pengilangan minyak bumi yang hanya terdiri dari kode 57, yakni industri pengilangan minyak Sektor ke 11 yakni sektor listrik, gas, dan air minum yang terdiri atas kode 68 listrik, kode 69 gas kota, dan kode 70 air bersih. Sektor ke 12 dalam agregasi ini adalah bangunan/konstruksi yang terdiri dari kode 71, bangunan/konstruksi. Sektor ke 13 adalah sektor perdagangan yang terdiri dari kode 72 perdagangan. Restoran dan hotel adalah klasifikasi sektor ke 14 dalam agregasi ini, yang terdiri dari kode 73 hotel, dan kode 74 restoran. Pengangkutan dan komunikasi menempati sektor 15 , yang terdiri dari kode 75 angkutan kereta api, kode 76 bus, kode 77 truk, kode 78 angkutan darat lainnya, kode 79 angkutan penyeberangan, kode 80 angkutan laut, kode 81 angkutan udara, kode 82 jasa penunjang angkutan, kode 83 pos dan giro, dan kode 84 telekomunikasi, serta kode 85 jasa penunjang komunikasi. Sektor 16 adalah lembaga keuangan, usaha bangunan, dan jasa perusahaan yang terdiri dari kode 86 
bank dan lembaga keuangan, kode 87 koperasi simpan pinjam, kode 88 asuransi kode 89 pasar modal, kode 90 jasa penunjang keuangan lainnya, kode 91 sewa bangunan, dan kode 92 jasa perusahaan. Sektor 17 adalah pemerintahan umum dan pertahanan yang terdiri dari kode 93 yakni pemerintahan umum dan pertanahan. Sektor 18 adalah sektor jasa-jasa yang terdiri dari kode 95 jasa pendidikan, kode 96 jasa kesehatan, kode 97 jasa kemasyarakatan lainnya, kode 94 jasa hiburan dan kebudayaan, dan kode 98 jasa perorangan dan rumah tangga. Sektor terkahir adalah sektor kegiatan yang tidak yakni sektor 19 .

\section{B. Tahap Pembuatan Matriks Koefisien Input Berdasarkan Tabel Input-Output Provinsi Jawa Timur Tahun Sampai Ta- hun 2015 Klasifikasi 19 Sektor}

Matriks koefisien input menggambarkan komposisi input antara yang digunakan masing-masing sektor dalam berproduksi. Secara umum, matriks koefisien input tidak perlu diterjemahkan secara matriks, akan tetapi penjumlahan secara baris mencerminkan keterkaitan langsung kedepan dan penjumlahan secara kolom mencerminkan keterkaitan langsung langsung kebelakang. Untuk lebih detail perhitungan matriks koefisien input berdasarkan tabel input-output tahun 2000 dapat dilihat pada lampiran D.1, tahun 2006 dapat dilihat pada lampiran D.2, tahun 2010 dapat dilihat pada lampiran D.3 dan matriks koefisien input tahun 2015 dilihat pada lampiran D.4

\section{Struktur Perekonomian Jawa Timur Berdasarkan Tabel Input-Output Tahun 2000 Sampai Tahun 2015}

Untuk melihat struktur perekonomian Jawa Timur dari tahun 2000 hingga 2015 dapat dilihat melalui tabel derivasi dari tabel utama input-output Jawa Timur. Analisis struktur perekonomian Jawa Timur dilihat dari keterkaitan langsung kedepan dan kebelakang masing-masing sektor, keterkaitan langsung tidak langsung kedepan dan kebelakang masing-masing sektor, dampak permintaan akhir terhadap output dan nilai tambah bruto, serta melihat nilai multiplier product matrix.

\section{Keterkaitan Langsung Tahun 2000}

Berdasarkan analisis keterkaitan langsung seperti gambar 2, untuk nilai keterkaitan langsung kebelakang yang tertinggi ada pada tahun 2000 adalah sektor 14 sebesar 0.53857123 , artinya jika terjadi peningkatan output pada sektor 14 , yakni sektor restoran dan hotel sebagai akibat permintaan akhir sektor restoran dan hotel itu sendiri, maka akan ada peningkatan penggunaan input produksi sektor restoran dan hotel secara langsung. Peningkatan penggunaan input adalah adalah peningkatan output karena total input sama dengan total output. Jika terjadi peningkatan satu unit uang output atau Rp.1 sektor restoran dan hotel, akan meningkatkan input sebesar Rp.0,53857123 penyusun sektor restoran dan hotel tersebut. Kondisi ini diikuti oleh sektor 12, yakni bangunan dan kontruksi dan peringkat ketiga oleh sektor 11 yakni sektor listrik, gas, dan air minum dengan masing-masing nilai keterkaitan langsung kebelakang sebesar 0.491999936 dan 0.410914875. Sektor yang tidak memiliki nilai keterkaitan kebelakang langsung adalah sektor 17 yakni pemerintahan umum dan pertahanan dan sektor 19 yakni sektor kegiatan yang tidak jelas batasnya yang dicerminkan nilai keterkaitan langsung kebelakang sebesar 0 . Keterkaitan kebelakang melihat peningkatan output melalui sisi permintaan input. 


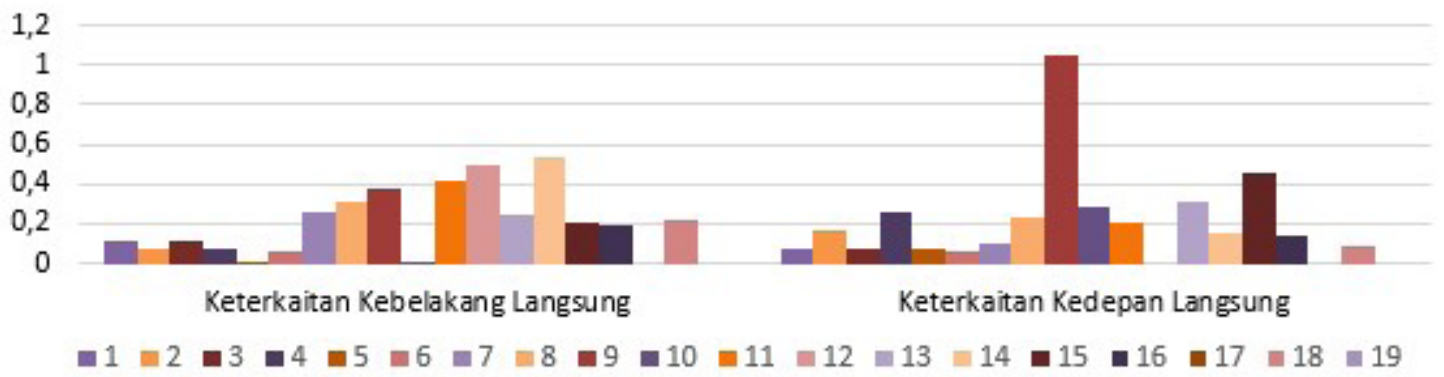

Gambar 2

Keterkaitan Langsung Tahun 2000

Keterangan : sektor (1) Padi, (2) Tanaman Bahan Makanan, (3) Tanaman Pertanian Lainnya, (4) Peternakan dan Hasil-hasilnya, (5) Kehutanan, (6) Perikanan, (7) Pertambangan dan Penggalian, (8) Industri Makanan, Minuman, dan Tembakau, (9) Industri Lainnya, (10) Pengilangan Minyak Bumi, (11) Listrik, Gas, dan Air Minum, (12) Bangunan/Konstruksi, (13) Perdagangan, (14) Restoran dan Hotel, (15) Pengangkutan dan Komunikasi, (16) Lembaga Keuangan, Usaha Bangunan, dan Jasa Perusahaan, (17) Pemerintahan Umum dan Pertahanan, (18) Jasa-jasa, 19) Kegiatan yang tidak jelas batasnya. Sumber : data sekunder diolah,2017

Nilai keterkaitan langsung kedepan dengan nilai tertinggi adalah sektor 9 dengan nilai 1,049444856. artinya jika terdapat kenaikan output pada sektor industri lainnya, maka aka nada peningkatan penggunaan output produksi dari sektor industri lainnya secara langsung. Jika terjadi peningkatan satu unit uang output atau Rp.1 sektor restoran dan hotel, akan meningkatkan penggunaan output sebesar Rp.1,049444856 dari sektor yang menggunakan industri lainnya sebagai inputnya.

Kondisi ini diikuti oleh sektor 15, yakni pengangkutan dan komunikasi dan peringkat ketiga oleh sektor 13 yakni sektor perdagangan dengan masing-masing nilai keterkaitan langsung kedepan sebesar 0.452454175 dan 0.312457636. Sektor yang tidak memiliki nilai keterkaitan kedepan langsung adalah sektor 12 yakni sektor bangunan/konstruksi, sektor 17 yakni pemerintahan umum dan pertahanan dan sektor 19 yakni sektor kegiatan yang tidak jelas batasnya yang dicerminkan nilai keterkaitan langsung kedepan sebesar 0 . Keterkaitan kedepan melihat peningkatan output melalui mekanisme penawaran output.
Nilai keterkaitan langsung kebelakang yang tertinggi adalah sektor 16 seperti gambar 3, yakni sektor lembaga keuangan, usaha bangunan dan jasa perusahaan. Nilai keterkaitan langsung kebelakang sektor ini 0,48473649 , artinya jika terjadi peningkatan output pada sektor lembaga keuangan, usaha bangunan dan jasa perusahaan sebagai akibat permintaan akhir sektor lembaga keuangan, usaha bangunan dan jasa perusahaan itu sendiri, maka akan ada peningkatan penggunaan input produksi sektor lembaga keuangan, usaha bangunan dan jasa perusahaan secara langsung. Peningkatan penggunaan input adalah adalah peningkatan output karena total input sama dengan total output. Jika terjadi peningkatan satu unit uang output atau Rp.1 sektor lembaga keuangan, usaha bangunan dan jasa perusahaan, akan meningkatkan input sebesar Rp. 0,48473649 penyusun sektor lembaga keuangan, usaha bangunan dan jasa perusahaan tersebut. 


\section{Keterkaitan Langsung Tahun 2006}

Kondisi ini diikuti oleh sektor 14, restoran dan hotel dan peringkat ketiga oleh sektor 11 yakni sektor listrik, gas, dan air minum dengan masing-masing nilai keterkaitan langsung kebelakang sebesar 0.370664665 dan 0.370634191. Sektor yang tidak memiliki nilai keterkaitan kebelakang langsung adalah sektor 19 yakni sektor kegiatan yang tidak jelas batasnya yang dicerminkan nilai keterkaitan langsung kebelakang sebesar 0 . Keterkaitan kebelakang melihat peningkatan output melalui sisi permintaan input.

Nilai keterkaitan langsung kedepan dengan nilai tertinggi adalah sektor 13 dengan nilai 0,894239553 artinya jika terdapat kenaikan output pada sektor perdagangan, maka aka nada peningkatan penggunaan output produksi dari sektor perdagangan secara langsung. Jika terjadi peningkatan satu unit uang output atau Rp. 1 sektor perdagangan, akan meningkatkan penggunaan output sebesar Rp.0,894239553 dari sektor yang menggunakan perdagangan sebagai inputnya. Kondisi ini diikuti oleh sektor 16, yakni sektor lembaga keuangan, usaha bangunan, dan jasa perusahaan dan peringkat ketiga oleh sektor 9 yakni sektor industri lainnya dengan masing-masing nilai keterkaitan langsung kedepan sebesar 0,646780067 dan 0,641454731. Sektor yang tidak memiliki nilai keterkaitan kedepan langsung adalah sektor 19 yakni sektor kegiatan yang tidak jelas batasnya yang dicerminkan nilai keterkaitan langsung kedepan sebesar 0 . Keterkaitan kedepan melihat peningkatan output melalui mekanisme penawaran output.

Nilai keterkaitan langsung kebelakang tahun 2010 yang tertinggi adalah sektor 8 seperti gambar 4 , yakni sektor industri makanan, minuman, dan tembakau.

Nilai keterkaitan langsung kebelakang sektor ini 0.567629796, artinya jika terjadi peningkatan output pada sektor industri makanan, minuman, dan tembakau sebagai akibat permintaan akhir sektor industri makanan, minuman, dan tembakau itu sendiri, maka akan ada peningkatan penggunaan input produksi sektor industri makanan, minuman, dan tembakau secara langsung. Peningkatan penggunaan input adalah adalah peningkatan output karena total input sama dengan total output. Jika

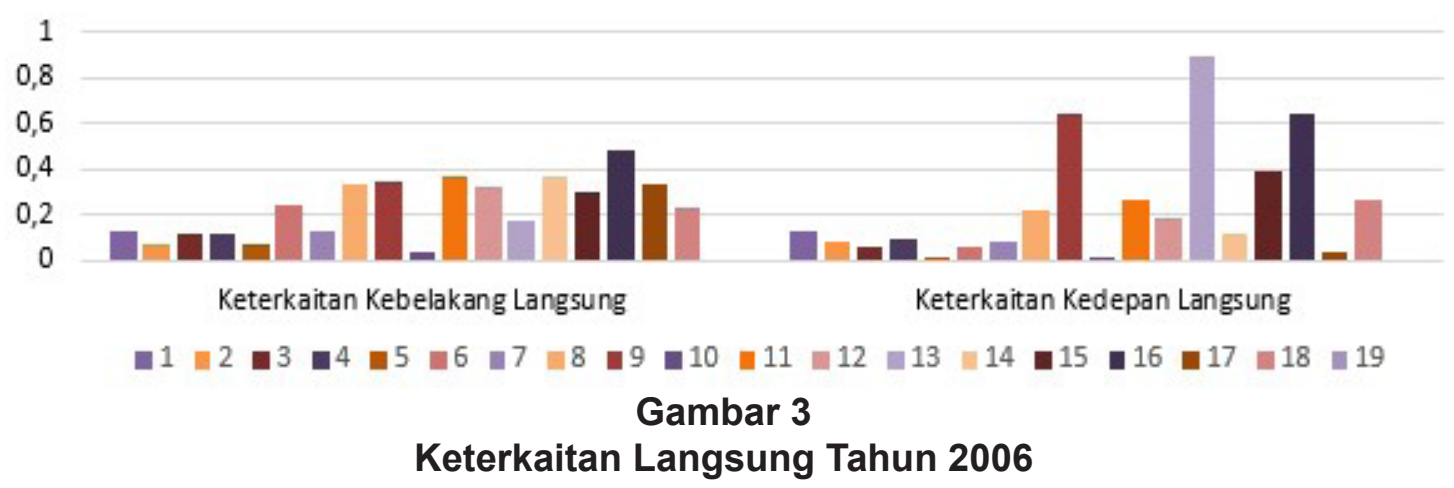

Keterangan : sektor (1) Padi, (2) Tanaman Bahan Makanan, (3) Tanaman Pertanian Lainnya, (4) Peternakan dan Hasil-hasilnya, (5) Kehutanan, (6) Perikanan, (7) Pertambangan dan Penggalian, (8) Industri Makanan, Minuman, dan Tembakau, (9) Industri Lainnya, (10) Pengilangan Minyak Bumi, (11) Listrik, Gas, dan Air Minum, (12) Bangunan/Konstruksi, (13) Perdagangan, (14) Restoran dan Hotel, (15) Pengangkutan dan Komunikasi, (16) Lembaga Keuangan, Usaha Bangunan, dan Jasa Perusahaan, (17) Pemerintahan Umum dan Pertahanan, (18) Jasa-jasa, 19) Kegiatan yang tidak jelas batasnya. Sumber : data sekunder diolah,2017 
terjadi peningkatan satu unit uang output atau Rp.1 industri makanan, minuman, dan tembakau, akan meningkatkan input sebesar Rp. 0,48473649 penyusun sektor industri makanan, minuman, dan tembakau tersebut. Kondisi ini diikuti oleh sektor 12 yakni bangunan/konstruksi dan peringkat ketiga oleh sektor 18 yakni sektor lembaga keuangan, usaha bangunan dan jasa perusahaan dengan masing-masing nilai keterkaitan langsung kebelakang sebesar 0.440295399 dan 0.401978199 .

\section{Keterkaitan Langsung Tahun 2010}

Sektor yang tidak memiliki nilai keterkaitan kebelakang langsung adalah sektor 19 yakni sektor kegiatan yang tidak jelas batasnya yang dicerminkan nilai keterkaitan langsung kebelakang sebesar 0 . Keterkaitan kebelakang melihat peningkatan output melalui sisi permintaan input.

Nilai keterkaitan langsung kedepan dengan nilai tertinggi adalah sektor 16 dengan nilai 1,349966574 artinya jika terdapat kenaikan output pada sektor lembaga keuangan, usaha bangunan dan jasa perusahaan, maka akan ada peningkatan penggunaan output produksi dari sektor lembaga keuangan, usaha bangunan dan jasa perusahaan secara langsung. Jika terjadi peningkatan satu unit uang output atau Rp.1 sektor lembaga keuangan, usaha bangunan dan jasa perusahaan, akan meningkatkan penggunaan output sebesar Rp.1,349966574 dari sektor yang menggunakan lembaga keuangan, usaha bangunan dan jasa perusahaan sebagai inputnya. Kondisi ini diikuti oleh sektor 19, yakni sektor kegiatan yang tidak jelas batasnya dan peringkat ketiga oleh sektor 8 yakni sektor industri makanan, minuman, dan tembakau dengan masing-masing nilai keterkaitan langsung kedepan sebesar 0,577823161 dan 0,415406364. Sektor yang memiliki nilai keterkaitan kedepan langsung terkecil pada tahun 2010 adalah sektor 17 yakni sektor pemerintahan umum dan pertahanan yang dicerminkan nilai keterkaitan langsung kedepan sebesar 0,009964703. Keterkaitan kedepan melihat peningkatan output melalui mekanisme penawaran output.

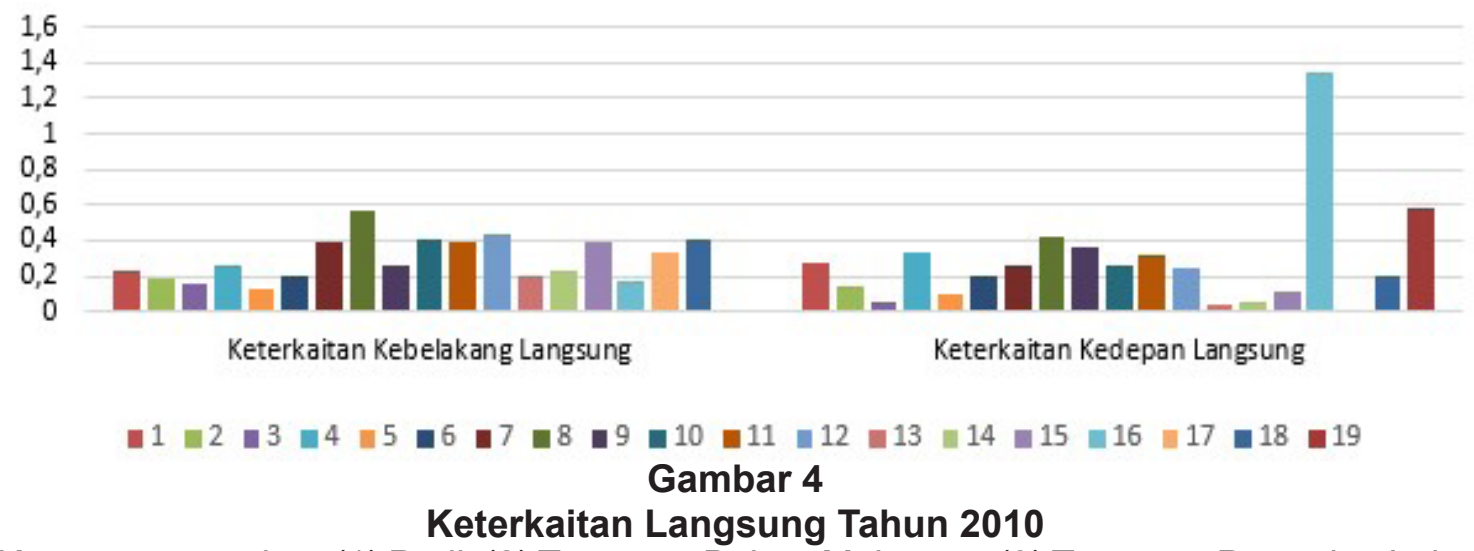

Keterangan : sektor (1) Padi, (2) Tanaman Bahan Makanan, (3) Tanaman Pertanian Lainnya, (4) Peternakan dan Hasil-hasilnya, (5) Kehutanan, (6) Perikanan, (7) Pertambangan dan Penggalian, (8) Industri Makanan, Minuman, dan Tembakau, (9) Industri Lainnya, (10) Pengilangan Minyak Bumi, (11) Listrik, Gas, dan Air Minum, (12) Bangunan/Konstruksi, (13) Perdagangan, (14) Restoran dan Hotel, (15) Pengangkutan dan Komunikasi, (16) Lembaga Keuangan, Usaha Bangunan, dan Jasa Perusahaan, (17) Pemerintahan Umum dan Pertahanan, (18) Jasa-jasa, 19) Kegiatan yang tidak jelas batasnya. Sumber : data sekunder diolah,2017 
Nilai keterkaitan langsung kebelakang tahun 2015 yang tertinggi adalah sektor 10 seperti gambar 5 , yakni sektor pengilangan minyak bumi. Nilai keterkaitan langsung kebelakang sektor ini 0.617672626 , artinya jika terjadi peningkatan output pada sektor pengilangan minyak bumi sebagai akibat permintaan akhir sektor pengilangan minyak bumi itu sendiri, maka akan ada peningkatan penggunaan input produksi sektor pengilangan minyak bumi secara langsung. Peningkatan penggunaan input adalah adalah peningkatan output karena total input sama dengan total output.

Jika terjadi peningkatan satu unit uang output atau Rp.1 pengilangan minyak bumi, akan meningkatkan input sebesar Rp. 0,48473649 penyusun sektor pengilangan minyak bumi tersebut. Kondisi ini diikuti oleh sektor 7 yakni pertambangan dan penggalian dan peringkat ketiga oleh sektor 9 yakni sektor industri lainnya dengan masing-masing nilai keterkaitan langsung kebelakang sebesar 0.599871089 dan 0.50758745 . Sektor yang tidak memiliki nilai keterkaitan kebelakang langsung adalah sektor 19 yakni sektor kegiatan yang tidak jelas batasnya yang dicerminkan nilai keterkaitan langsung kebelakang sebesar 0 . Keterkaitan kebelakang melihat peningkatan output melalui sisi permintaan input.

\section{Keterkaitan Langsung Tahun 2015}

Nilai keterkaitan langsung kedepan dengan nilai tertinggi adalah sektor 9 dengan nilai 1,28368348 artinya jika terdapat kenaikan output pada sektor indsutri lainnya, maka akan ada peningkatan penggunaan output produksi dari sektor indsutri lainnya secara langsung. Jika terjadi peningkatan satu unit uang output atau Rp.1 sektor lembaga keuangan, usaha bangunan dan jasa perusahaan, akan meningkatkan penggunaan output sebesar Rp.1,28368348 dari sektor yang menggunakan indsutri lainnya sebagai inputnya. Kondisi ini diikuti oleh sektor 15, yakni sektor pengangkutan dan komunikasi dan peringkat ketiga oleh sektor 8 yakni sektor industri makanan, minuman, dan tembakau dengan masing-masing nilai keterkaitan langsung kedepan sebesar 1,116572985 dan 0,49460985.

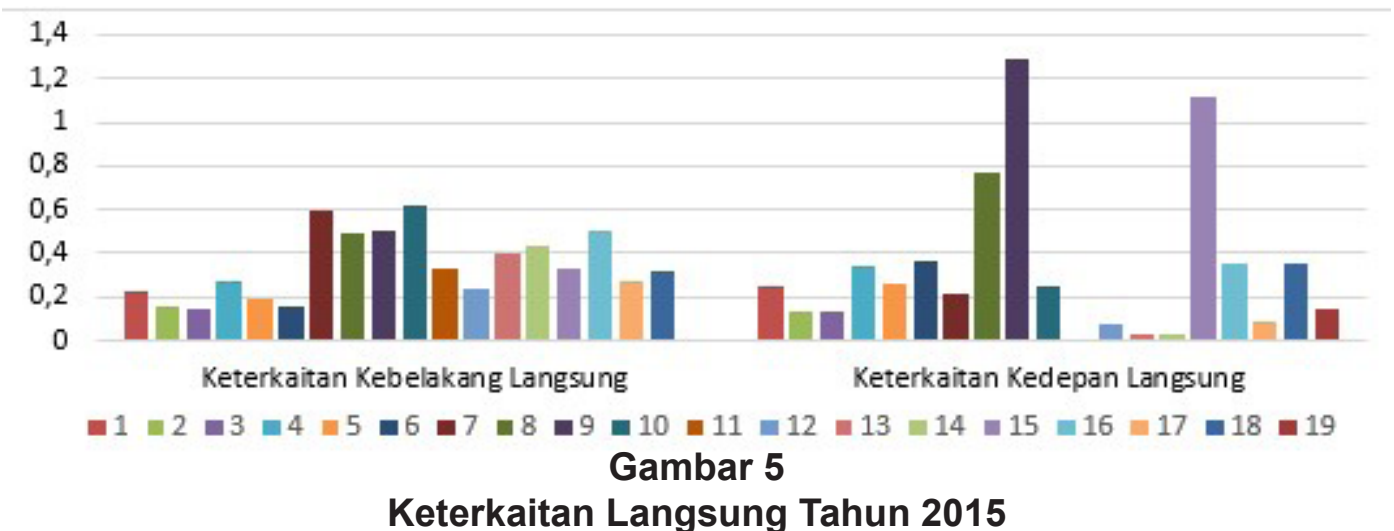

Keterangan : sektor (1) Padi, (2) Tanaman Bahan Makanan, (3) Tanaman Pertanian Lainnya, (4) Peternakan dan Hasil-hasilnya, (5) Kehutanan, (6) Perikanan, (7) Pertambangan dan Penggalian, (8) Industri Makanan, Minuman, dan Tembakau, (9) Industri Lainnya, (10) Pengilangan Minyak Bumi, (11) Listrik, Gas, dan Air Minum, (12) Bangunan/Konstruksi, (13) Perdagangan, (14) Restoran dan Hotel, (15) Pengangkutan dan Komunikasi, (16) Lembaga Keuangan, Usaha Bangunan, dan Jasa Perusahaan, (17) Pemerintahan Umum dan Pertahanan, (18) Jasa-jasa, 19) Kegiatan yang tidak jelas batasnya. Sumber : data sekunder diolah,2017 
5. Keterkaitan Langsung Kebelakang Tahun 2000 sampai Tahun 2015

Untuk melihat perkembangan keterkaitan sektor langsung kebelakang dari tahun 2000 sampai tahun 2015 dapat dilihat dari tabel 3. Dari tabel 3 dapat di intrepetasikan bahwa dominasi sektor yang memiliki nilai keterkaitan kebelakang tertinggi selalu mengalami perubahan dari tahun 2000 hingga tahun 2015. Pada tahun 2000 sektor 14 yakni restoran dan hotel menjadi sektor yang memiliki keterkaitan langsung kebelakang tertinggi, tahun 2006 sektor 16 yakni lembaga keuangan, usaha bangunan, dan jasa perusahaan, tahun 2010 sektor 8 industri makanan, minuman, dan tembakau, dan tahun 2015 sektor 10 yakni pengilangan minyak bumi yang menjadi sektor dengan nilai keterkaitan langsung kebelakang tertinggi.

Untuk melihat keterkaitan langsung kedepan tahun 2000 sampai tahun 2015 dapat dilihat dari tabel 4.

Tabel 3

Keterkaitan Kebelakang Langsung Tahun 2000 sampai Tahun 2015

\begin{tabular}{|c|c|c|c|c|c|c|c|c|}
\hline \multirow{2}{*}{ Ranking } & \multicolumn{8}{|c|}{ Keterkaitan Kebelakang Langsung } \\
\hline & Sektor & 2000 & Sektor & 2006 & Sektor & 2010 & Sektor & 2015 \\
\hline 1 & 14 & 0.53857123 & 16 & 0.48473649 & 8 & 0.567629796 & 10 & 0.617672626 \\
\hline 2 & 12 & 0.491999936 & 14 & 0.370664665 & 12 & 0.440295399 & 7 & 0.599871089 \\
\hline 3 & 11 & 0.410914875 & 11 & 0.370634191 & 18 & 0.401978199 & 9 & 0.50758745 \\
\hline 4 & 9 & 0.380736114 & 9 & 0.348190625 & 10 & 0.400552241 & 16 & 0.4980931 \\
\hline 5 & 8 & 0.311855747 & 17 & 0.33815377 & 11 & 0.392602763 & 8 & 0.49460985 \\
\hline 6 & 7 & 0.26044843 & 8 & 0.327363147 & 15 & 0.389257311 & 14 & 0.431778296 \\
\hline 7 & 13 & 0.250435577 & 12 & 0.317127117 & 7 & 0.385202547 & 13 & 0.400135396 \\
\hline 8 & 18 & 0.221018521 & 15 & 0.300528622 & 17 & 0.329526414 & 11 & 0.334772516 \\
\hline 9 & 15 & 0.207619981 & 6 & 0.245764797 & 4 & 0.261964683 & 15 & 0.325912761 \\
\hline 10 & 16 & 0.190277042 & 18 & 0.229723035 & 9 & 0.261377612 & 18 & 0.322499948 \\
\hline 11 & 1 & 0.115040011 & 13 & 0.178237735 & 14 & 0.23158108 & 4 & 0.271335374 \\
\hline 12 & 3 & 0.106580105 & 1 & 0.129579746 & 1 & 0.228103651 & 17 & 0.27058995 \\
\hline 13 & 4 & 0.075641431 & 7 & 0.125676824 & 13 & 0.204320732 & 12 & 0.238504193 \\
\hline 14 & 2 & 0.075036608 & 3 & 0.118415826 & 6 & 0.199180404 & 1 & 0.22186477 \\
\hline 15 & 6 & 0.056392854 & 4 & 0.116572612 & 2 & 0.188816945 & 5 & 0.195565074 \\
\hline 16 & 10 & 0.013582789 & 5 & 0.068109211 & 16 & 0.170939468 & 6 & 0.160316525 \\
\hline 17 & 5 & 0.00997872 & 2 & 0.064451373 & 3 & 0.164105009 & 2 & 0.1589219 \\
\hline 18 & 17 & 0 & 10 & 0.035250263 & 5 & 0.126689251 & 3 & 0.146042286 \\
\hline 19 & 19 & 0 & 19 & 0 & 19 & 0 & 19 & 0 \\
\hline
\end{tabular}

Keterangan : sektor (1) Padi, (2) Tanaman Bahan Makanan, (3) Tanaman Pertanian Lainnya, (4) Peternakan dan Hasil-hasilnya, (5) Kehutanan, (6) Perikanan, (7) Pertambangan dan Penggalian, (8) Industri Makanan, Minuman, dan Tembakau, (9) Industri Lainnya, (10) Pengilangan Minyak Bumi, (11) Listrik, Gas, dan Air Minum, (12) Bangunan/Konstruksi, (13) Perdagangan, (14) Restoran dan Hotel, (15) Pengangkutan dan Komunikasi, (16) Lembaga Keuangan, Usaha Bangunan, dan Jasa Perusahaan, (17) Pemerintahan Umum dan Pertahanan, (18) Jasa-jasa,19)Kegiatan yang tidak jelas batasnya. Keterkaitan Langsung Kedepan Tahun 2000 sampai Tahun 2015.

Sumber: data sekunder diolah, 2017 
Perubahan Landscape Ekonomi....... MediaTrend 13 (2) 2018 p.343-374

Tabel 4

Keterkaitan Kedepan Langsung Tahun 2000 sampai Tahun 2015

\begin{tabular}{ccccccccc}
\hline \multirow{2}{*}{ Ranking } & \multicolumn{7}{c}{ Keterkaitan Kedepan Langsung } \\
\cline { 2 - 9 } & Sektor & $\mathbf{2 0 0 0}$ & Sektor & $\mathbf{2 0 0 6}$ & Sektor & $\mathbf{2 0 1 0}$ & Sektor & $\mathbf{2 0 1 5}$ \\
\hline \hline $\mathbf{1}$ & 9 & 1.049444856 & 13 & 0.894239553 & 16 & 1.349966574 & 9 & 1.28368348 \\
$\mathbf{2}$ & 15 & 0.452454175 & 16 & 0.646780067 & 19 & 0.577823161 & 15 & 1.116572985 \\
$\mathbf{3}$ & 13 & 0.312457636 & 9 & 0.641454731 & 8 & 0.415406364 & 8 & 0.767677663 \\
$\mathbf{4}$ & 10 & 0.284987188 & 15 & 0.392124253 & 9 & 0.369159141 & 6 & 0.36560192 \\
$\mathbf{5}$ & 4 & 0.254463677 & 11 & 0.265265233 & 4 & 0.330059141 & 18 & 0.356991481 \\
$\mathbf{6}$ & 8 & 0.227157847 & 18 & 0.260202984 & 11 & 0.317245643 & 16 & 0.349867223 \\
$\mathbf{7}$ & 11 & 0.208075744 & 8 & 0.21995435 & 1 & 0.272565263 & 4 & 0.345191867 \\
$\mathbf{8}$ & 2 & 0.162413823 & 12 & 0.187114999 & 10 & 0.262728776 & 5 & 0.262283454 \\
$\mathbf{9}$ & 14 & 0.1553122 & 1 & 0.128199059 & 7 & 0.261024867 & 1 & 0.248580964 \\
10 & 16 & 0.136149726 & 14 & 0.117897561 & 12 & 0.249341775 & 10 & 0.244352176 \\
11 & 7 & 0.106433822 & 4 & 0.094609835 & 18 & 0.205639924 & 7 & 0.208820423 \\
12 & 18 & 0.08655617 & 2 & 0.079718325 & 6 & 0.196991403 & 19 & 0.147383542 \\
13 & 3 & 0.073642002 & 7 & 0.076196837 & 2 & 0.149242458 & 2 & 0.137911742 \\
14 & 1 & 0.072466008 & 6 & 0.058223929 & 15 & 0.117320924 & 3 & 0.130323322 \\
15 & 5 & 0.072210697 & 3 & 0.056077392 & 5 & 0.101965493 & 17 & 0.089063163 \\
16 & 6 & 0.061904402 & 17 & 0.033435431 & 14 & 0.06131197 & 12 & 0.074293293 \\
17 & 12 & 0 & 10 & 0.012563046 & 3 & 0.059314435 & 14 & 0.03061078 \\
18 & 17 & 0 & 5 & 0.005122461 & 13 & 0.037051493 & 13 & 0.028140318 \\
19 & 19 & 0 & 19 & 0 & 17 & 0.009964703 & 11 & 0.008723306 \\
\hline
\end{tabular}

Keterangan : sektor (1) Padi, (2) Tanaman Bahan Makanan, (3) Tanaman Pertanian Lainnya, (4) Peternakan dan Hasil-hasilnya, (5) Kehutanan, (6) Perikanan, (7) Pertambangan dan Penggalian, (8) Industri Makanan, Minuman, dan Tembakau, (9) Industri Lainnya, (10) Pengilangan Minyak Bumi, (11) Listrik, Gas, dan Air Minum, (12) Bangunan/Konstruksi, (13) Perdagangan, (14) Restoran dan Hotel, (15) Pengangkutan dan Komunikasi, (16) Lembaga Keuangan, Usaha Bangunan, dan Jasa Perusahaan, (17) Pemerintahan Umum dan Pertahanan, (18) Jasa-jasa, 19) Kegiatan yang tidak jelas batasnya.

Sumber: data sekunder diolah, 2017

6. Keterkaitan Langsung Tidak Langsung Tahun 2000

Keterkaitan langsung tidak langsung memasukkan unsur external shock atau secara eksogen (terjadi penambahan output) dalam mempengaruhi terjadinya perubahan total. Keterkaitan langsung tidak langsung dibedakan menjadi dua, yakni keterkaitan langsung tidak langsung kebelakang dan keterkaitan langsung tidak langsung kedepan.

Keterkaitan langsung tidak langsung kebelakang oleh Rasmussen (Nazara, 2005:187) memiliki arti sebagai power dispertion for the backward linkage atau sebagai daya penyebaran dari keterkaitan kebelakang.
Keterkaitan langsung tidak langsung kedepan oleh Rasmussen (Nazara, 2005:187) memiliki arti sebagai indices of sensivity of dispertion for forward linkage atau sebagai derajat kepekaan dari keterkaitan kedepan. Perhatikan grafik 5 berikut.

Dari gambar 6 dapat diketahui bahwa daya penyebaran pada tahun 2000 yang tertinggi adalah sektor 12, yakni sektor bangunan/konstruksi sebesar 1,356850291 yang berarti daya penyebaran sektor bangunan/konstruksi diatas rata-rata daya rata-rata penyebaran seluruh sektor ekonomi. Daya penyebaran yang diatas seluruh ekonomi lainnya adalah sektor 14 yakni sektor restoran dan ho- 
tel, sektor 11 yakni sektor listrik, gas, dan air minum, sektor 9 yakni industri lainnya, sektor 8 yakni industri makanan, minuman, dan tembakau, sektor 7 yakni sektor pertambangan dan penggalian, sektor 13 yakni sektor perdagangan, sektor 18 yakni jasa-jasa , sektor 16 yakni lembaga keuangan, usaha bangunan, dan jasa perusahaan, karena memiliki nilai daya penyebaran lebih dari 1, sedangkan sektor yang lain yang tidak disebut daya penyebarannya dibawah rata-rata daya penyebaran sektor ekonomi dan nilai yang paling kecil adalah sektor 17 dan 19, yakni sektor pemerintahan umum dan pertahanan dan sektor kegiatan yang tidak jelas batasnya dengan koefisien yang sam sebesar 0,792928339 . sektor 15 pengangkutan dan komunikasi, sektor 13 perdagangan, sektor 10 pengilangan minyak, sektor 4 peternakan dan hasil-hasilnya, sektor 8 industri makanan, minuman, dan tembakau, sektor 11 listrik, gas, dan air minum. Sektor-sektor yang disebutkan diatas memiliki nilai derajat kepekaan lebih dari 1 yang artinya derajat kepekaan sektor tersebut diatas rata-rata derajat kepekaan seluruh sektor ini. Nilai derajat kepekaan pada tahun 2000 yang terendah adalah sektor 12 bangunan dan konstruksi, sektor 17 pemerintahan umum dan pertahanan, dan sektor 19 dengan nilai derajat kepekeaan yang sama, sebesar 0.792928339 .

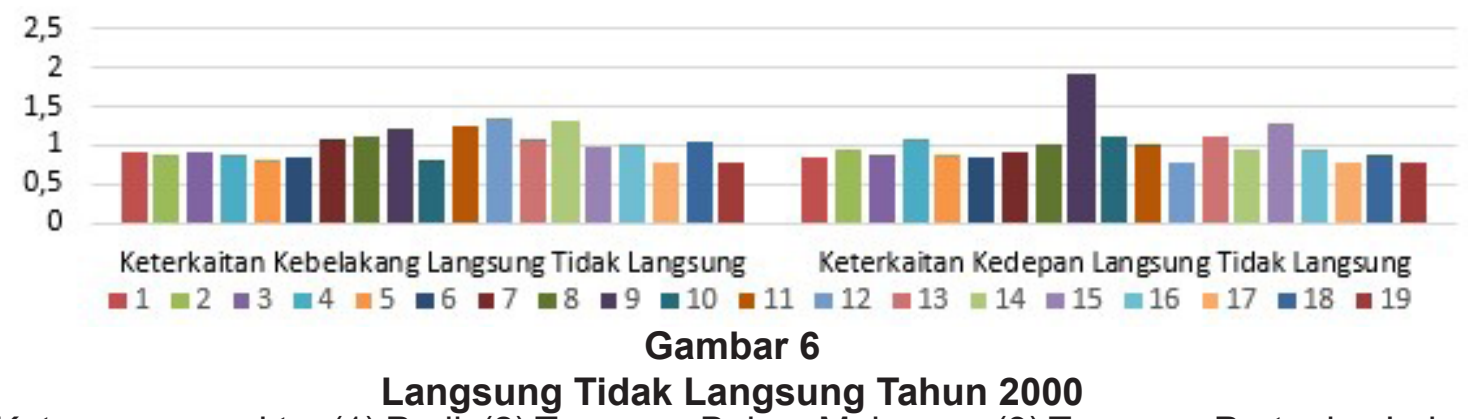

Keterangan : sektor (1) Padi, (2) Tanaman Bahan Makanan, (3) Tanaman Pertanian Lainnya, (4) Peternakan dan Hasil-hasilnya, (5) Kehutanan, (6) Perikanan, (7) Pertambangan dan Penggalian, (8) Industri Makanan, Minuman, dan Tembakau, (9) Industri Lainnya, (10) Pengilangan Minyak Bumi, (11) Listrik, Gas, dan Air Minum, (12) Bangunan/Konstruksi, (13) Perdagangan, (14) Restoran dan Hotel, (15) Pengangkutan dan Komunikasi, (16) Lembaga Keuangan, Usaha Bangunan, dan Jasa Perusahaan, (17) Pemerintahan Umum dan Pertahanan, (18) Jasa-jasa, 19) Kegiatan yang tidak jelas batasnya.

Sumber: data sekunder diolah, 2017

Derajat kepekaan akan tercermin dari nilai keterkaitan langsung tidak langsung kedepan. Nilai derajat kepekaan juga dapat dijadikan untuk menentukan sektor unggulan dalam perekonomian. Sektor dengan keterkaitan paling tinggi berarti memiliki potensi menghasilkan output produksi paling tinggi pula. Nilai derajat kepekaan tertinggi tahun 2000 adalah sektor 9 sektor industri lainnya dengan nilai derajat kepekaan sebesar 1,926834465, disusul
7.Keterkaitan Langsung Tidak Langsung Tahun 2006

Keterkaitan langsung tidak langsung kebelakang atau power dispertion for the backward linkage dan keterkaitan kedepan langsung tidak langsung atau indices of sensivity of dispertion for forward linkage tahun 2006 tercermin pada gambar 7 . 


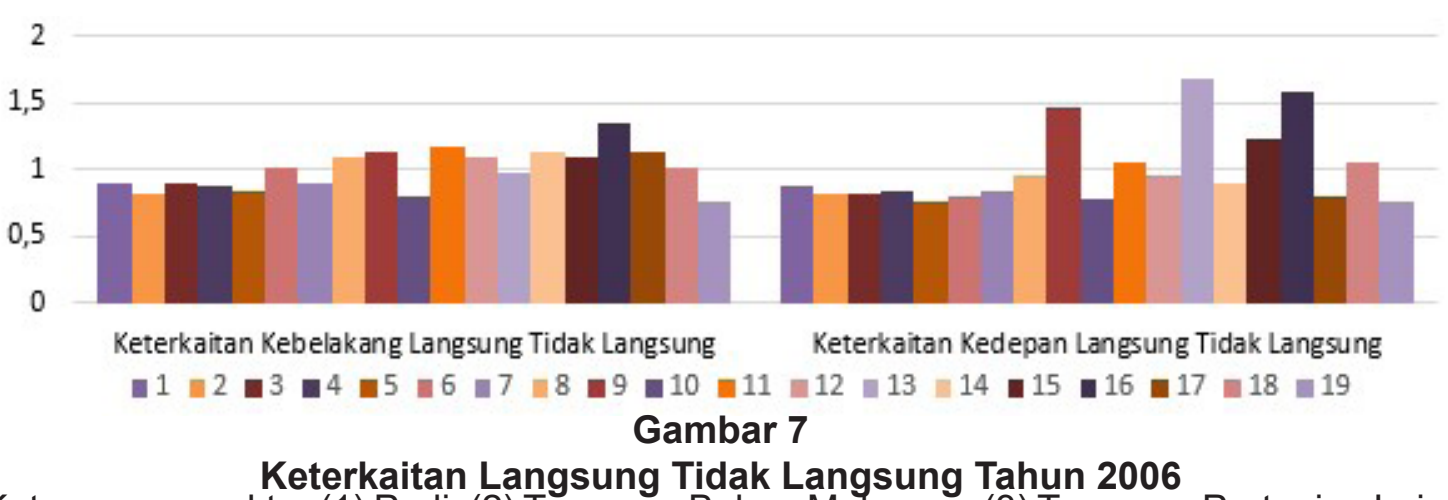

Keterangan : sektor (1) Padi, (2) Tanaman Bahan Makanan, (3) Tanaman Pertanian Lainnya, (4) Peternakan dan Hasil-hasilnya, (5) Kehutanan, (6) Perikanan, (7) Pertambangan dan Penggalian, (8) Industri Makanan, Minuman, dan Tembakau, (9) Industri Lainnya, (10) Pengilangan Minyak Bumi, (11) Listrik, Gas, dan Air Minum, (12) Bangunan/Konstruksi, (13) Perdagangan, (14) Restoran dan Hotel, (15) Pengangkutan dan Komunikasi, (16) Lembaga Keuangan, Usaha Bangunan, dan Jasa Perusahaan, (17) Pemerintahan Umum dan Pertahanan, (18) Jasa-jasa, 19) Kegiatan yang tidak jelas batasnya.

Sumber: data sekunder diolah, 2017

Dari gambar 7 di dapat diketahui bahwa daya penyebaran pada tahun 2000 yang tertinggi adalah sektor 16, yakni sektor lembaga keuangan, usaha bangunan, dan jasa perusahaan sebesar 1,344209424 yang berarti daya penyebaran sektor lembaga keuangan, usaha bangunan, dan jasa perusahaan diatas rata-rata daya rata-rata penyebaran seluruh sektor ekonomi. Daya penyebaran yang diatas seluruh ekonomi lainnya adalah sektor 11 yakni sektor listrik, gas, dan air minum, sektor 9 yakni industri lainnya, sektor 14 restoran dan hotel, sektor 17 pemerintahan umum dan pertahanan, sektor 12 bangunan/konstruksi, sektor 15 pengangkutan dan komunikasi, sektor 8 industri makanan, minuman, dan tembakau, sektor 18 jasa-jasa, sektor 6 perikanan, karena memiliki nilai daya penyebaran lebih dari 1 , sedangkan sektor yang lain yang tidak disebut daya penyebarannya dibawah rata-rata daya penyebaran sektor ekonomi dan nilai yang paling kecil adalah sektor 19, yakni sektor kegiatan yang tidak jelas batasnya dengan koefisien sebesar 0,760600505 .
Derajat kepekaan tahun 2006 akan tercermin dari nilai keterkaitan langsung tidak langsung kedepan. Nilai derajat kepekaan juga dapat dijadikan untuk menentukan sektor unggulan dalam perekonomian. Sektor dengan keterkaitan paling tinggi berarti memiliki potensi menghasilkan output produksi paling tinggi pula. Nilai derajat kepekaan tertinggi tahun 2006 adalah sektor 13 perdagangan dengan nilai derajat kepekaan sebesar 1,673551563, disusul sektor 16 lembaga keuangan, usaha bangunan, dan jasa perusahaan, sektor 9 industri lainnya , sektor 15 pengangkutan dan komunikasi, sektor 11 listrik, gas, dan air minum, sektor 18 jasa-jasa. Sektor-sektor yang disebutkan diatas memiliki nilai derajat kepekaan lebih dari 1 yang artinya derajat kepekaan sektor tersebut diatas rata-rata derajat kepekaan seluruh sektor ini. Nilai derajat kepekaan pada tahun 2006 yang terendah adalah sektor 19 kegiatan yang tidak jelas batasnya dengan nilai derajat kepekeaan yang sama, sebesar 0.760600505 . 
8.Keterkaitan Langsung Tidak Langsung Tahun 2010

Keterkaitan langsung tidak langsung kebelakang atau power dispertion for the backward linkage dan keterkaitan kedepan langsung tidak langsung atau indices of sensivity of dispertion for forward linkage tercermin pada gambar 8.

Dari gambar 8 di dapat diketahui bahwa daya penyebaran pada tahun 2000 yang tertinggi adalah sektor 8 , yakni sektor industri makanan, minuman, dan tembakau sebesar 1,309497591 yang berarti daya penyebaran sektor industri makanan, minuman, dan tembakau diatas rata-rata daya rata-rata penyebaran seluruh sektor ekonomi. Daya penyebaran yang diatas seluruh ekonomi lainnya adalah sektor 12 bangunan/konstruksi, sektor 18 jasa-jasa, sektor 11 listrik, gas, dan air minum, sektor 15 pengangkutan dan komunikasi, sektor 10 pengilangan minyak bumi, sektor 7 pertambangan dan penggalian sektor pertambangan dan penggalian, karena memiliki nilai daya penyebaran lebih dari 1 , sedangkan sektor yang lain yang tidak disebut daya penyebarannya dibawah rata-rata daya penyebaran sektor ekonomi dan nilai yang paling kecil adalah sektor 19 , yakni sektor kegiatan yang tidak jelas batasnya dengan koefisien yang sama sebesar 0,7244201041 .

Derajat kepekaan akan tercermin dari nilai keterkaitan langsung tidak langsung kedepan. Nilai derajat kepekaan juga dapat dijadikan untuk menentukan sektor unggulan dalam perekonomian. Sektor dengan keterkaitan paling tinggi berarti memiliki potensi menghasilkan output produksi paling tinggi pula. Nilai derajat kepekaan tertinggi tahun 2010 adalah sektor 16 lembaga keuangan, usaha bangunan, dan jasa perusahaan dengan nilai derajat kepekaan sebesar 2,043307244, disusul sektor 19 kegiatan yang tidak jelas batasannya, sektor 8 industri makanan, minuman, dan tembakau, sektor 9 industri lainnya, sektor 4 peternakan dan hasilhasilnya, sektor 1 padi, sektor 11 listrik, gas, dan air minum. Sektor-sektor yang disebutkan diatas memiliki nilai derajat kepekaan lebih dari 1 yang artinya derajat kepekaan sektor tersebut diatas rata-rata derajat kepekaan seluruh sektor ini. nilai derajat kepekaan pada tahun 2010 yang terendah adalah sektor 17 pemerintahan umum dan pertahanan dengna nilai derajat kepekaan sebesar 0.732982508 .

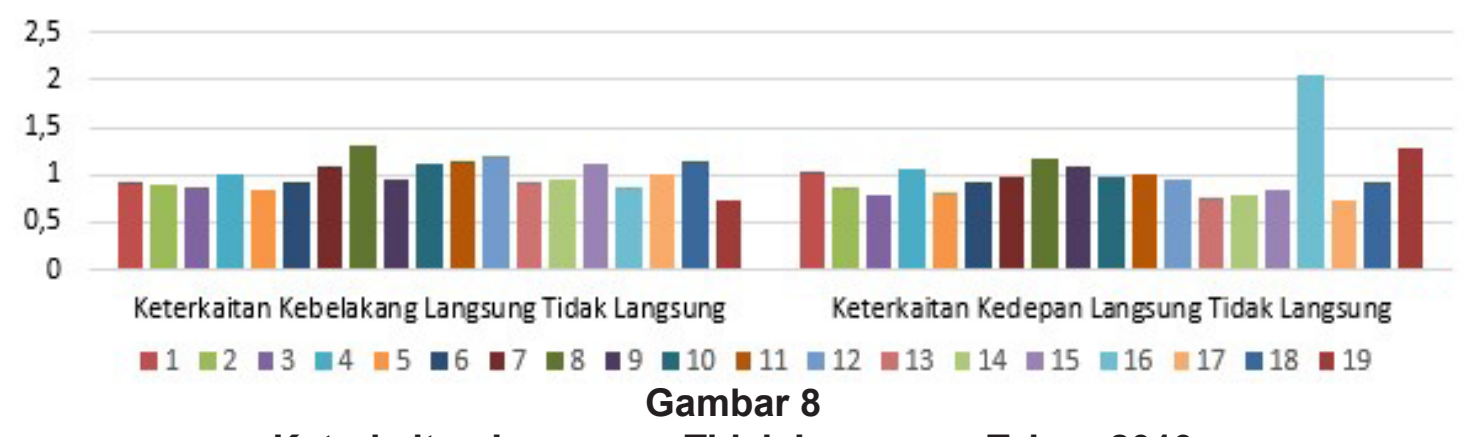

Keterkaitan Langsung Tidak Langsung Tahun 2010

Keterangan : sektor (1) Padi, (2) Tanaman Bahan Makanan, (3) Tanaman Pertanian Lainnya, (4) Peternakan dan Hasil-hasilnya, (5) Kehutanan, (6) Perikanan, (7) Pertambangan dan Penggalian, (8) Industri Makanan, Minuman, dan Tembakau, (9) Industri Lainnya, (10) Pengilangan Minyak Bumi, (11) Listrik, Gas, dan Air Minum, (12) Bangunan/Konstruksi, (13) Perdagangan, (14) Restoran dan Hotel, (15) Pengangkutan dan Komunikasi, (16) Lembaga Keuangan, Usaha Bangunan, dan Jasa Perusahaan, (17) Pemerintahan Umum dan Pertahanan, (18) Jasa-jasa, 19) Kegiatan yang tidak jelas batasnya.

Sumber: data sekunder diolah, 2017 
9. Keterkaitan Langsung Tidak Langsung Tahun 2015

Keterkaitan langsung tidak langsung kebelakang atau power dispertion for the backward linkage dan keterkaitan kedepan langsung tidak langsung atau indices of sensivity of dispertion for forward linkage tercermin pada gambar 9 .

Dari gambar 9 dapat diketahui bahwa daya penyebaran pada tahun 2000 yang tertinggi adalah sektor 7 , yakni sektor pertambangan dan penggalian sebesar 1,258510464 yang berarti daya penyebaran sektor pertambangan dan penggalian diatas rata-rata daya rata-rata penyebaran seluruh sektor ekonomi. Daya penyebaran yang diatas seluruh ekonomi lainnya adalah sektor 10 pengilangan minyak bumi, sektor 9 yakni industri lainnya, sektor 16 yakni lembaga keuangan, usaha bangunan, dan jasa perusahaan sektor 14 sektor restoran dan hotel, sektor 8 yakni industri makanan, minuman, dan tembakau, sektor 13 perdagangan, sektor 11 yakni sektor listrik, gas, dan air minum, sektor 15 pengangkutan dan komunikasi, karena memiliki nilai daya penyebaran lebih dari 1 , sedangkan sektor yang lain yang tidak disebut daya penyebarannya dibawah rata-rata daya penyebaran sektor ekonomi dan nilai yang paling kecil sektor 19, yakni sektor kegiatan yang tidak jelas batasnya dengan koefisien sebesar 0,655806254

Derajat kepekaan akan tercermin dari nilai keterkaitan langsung tidak langsung kedepan. Nilai derajat kepekaan juga dapat dijadikan untuk menentukan sektor unggulan dalam perekonomian. Sektor dengan keterkaitan paling tinggi berarti memiliki potensi menghasilkan output produksi paling tinggi pula. Nilai derajat kepekaan tertinggi tahun 2015 adalah sektor 9 sektor industri lainnya dengan nilai derajat kepekaan sebesar 2,072322327, disusul sektor 15 pengangkutan dan komunikasi, sektor 8 industri makanan, minuman, dan tembakau, sektor 18 jasa-jasa, sektor 6 perikanan, sektor 16 lembaga keuangan, usaha bangunan, dan jasa perusahaan. Sektor-sektor yang disebutkan diatas memiliki nilai derajat kepekaan lebih dari 1 yang artinya derajat kepekaan sektor

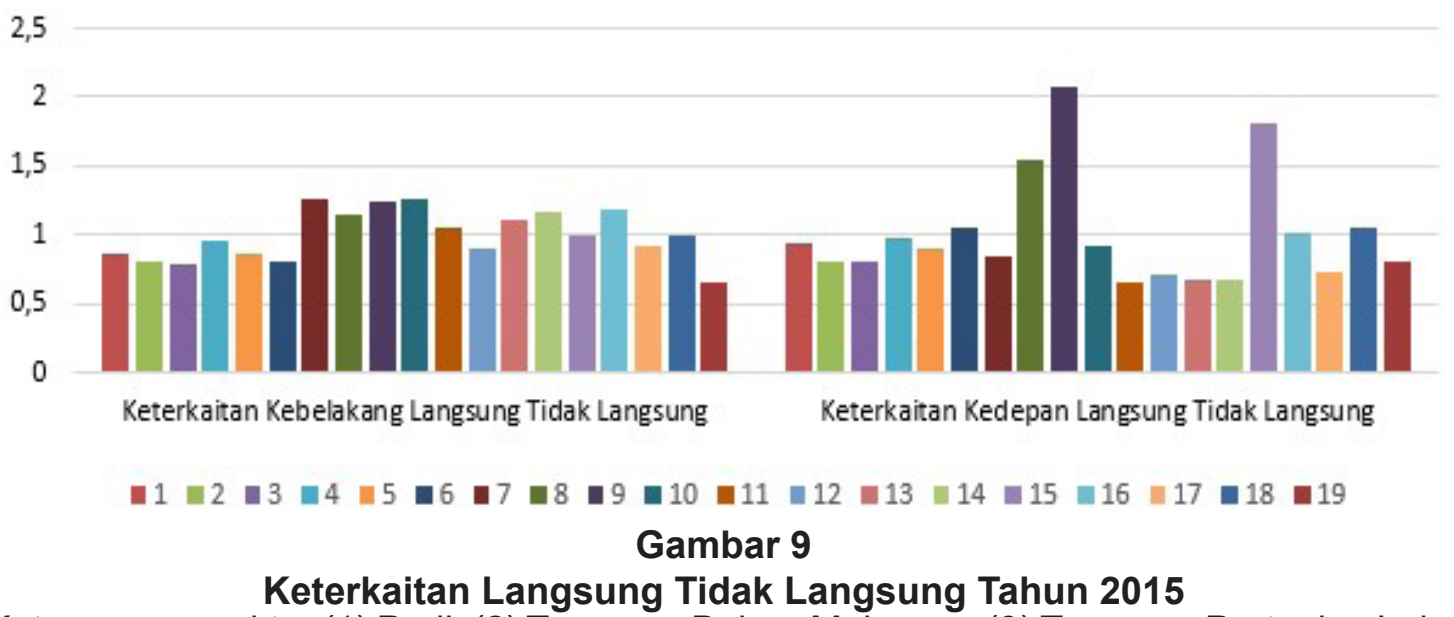

Keterangan : sektor (1) Padi, (2) Tanaman Bahan Makanan, (3) Tanaman Pertanian Lainnya, (4) Peternakan dan Hasil-hasilnya, (5) Kehutanan, (6) Perikanan, (7) Pertambangan dan Penggalian, (8) Industri Makanan, Minuman, dan Tembakau, (9) Industri Lainnya, (10) Pengilangan Minyak Bumi, (11) Listrik, Gas, dan Air Minum, (12) Bangunan/ Konstruksi, (13) Perdagangan, (14) Restoran dan Hotel, (15) Pengangkutan dan Komunikasi, (16) Lembaga Keuangan, Usaha Bangunan, dan Jasa Perusahaan, (17) Pemerintahan Umum dan Pertahanan, (18) Jasa-jasa, 19) Kegiatan yang tidak jelas batasnya Sumber: data sekunder diolah, 2017 
tersebut diatas rata-rata derajat kepekaan seluruh sektor ini. nilai derajat kepekaan pada tahun 2015 yang terendah adalah sektor 11 listrik, gas, dan air minum dengan nilai derajat kepekeaan yang sama, sebesar 0,663660112 .

10. Keterkaitan Langsung Tidak Langsung Kedepan Tahun 2000 sampai Tahun 2015.

Secara umum, keterkaitan kebelakang langsung tidak langsung atau power dispersion for the backward linkage dari tahun 2000 sampai dengan tahun 2015 akan dipaparkan pada tabel 5 .
Dari tabel 5 terlihat nilai power dispersion for the backward linkage Jawa Timur semakin menurun dengan sektor yang menduduki peringkat pertama berbeda disetiap tahunnya. Pada tahun 2000 sektor 12 bangunan/konstruksi menjadi sektor yang menduduki peringkat pertama dengan nilai daya penyebaran sebesar 1,356850291 , pada tahun berikutnya sektor 16 lembaga keuangan, usaha bangunan, dan jasa perusahaan menduduki peringkat pertama dengan nilai derajat penyebaran yang lebih kecil dari periode sebelumnya yakni 1,344209424 . Tahun

Tabel 5

Daya Penyebaran Tahun 2000 sampai Tahun 2015

\begin{tabular}{|c|c|c|c|c|c|c|c|c|}
\hline \multirow{2}{*}{ Ranking } & \multicolumn{8}{|c|}{ Keterkaitan Kebelakang Langsung Tidak Langsung } \\
\hline & Sektor & 2000 & Sektor & 2006 & Sektor & 2010 & Sektor & 2015 \\
\hline 1 & 12 & 1.356850291 & 16 & 1.344209424 & 8 & 1.309497591 & 7 & 1.258510464 \\
\hline 2 & 14 & 1.30206473 & 11 & 1.172189508 & 12 & 1.202113422 & 10 & 1.255659907 \\
\hline 3 & 11 & 1.238382319 & 9 & 1.141868035 & 18 & 1.150646324 & 9 & 1.239647276 \\
\hline 4 & 9 & 1.202128027 & 14 & 1.138005885 & 11 & 1.133894197 & 16 & 1.190319615 \\
\hline 5 & 8 & 1.115450556 & 17 & 1.134807761 & 15 & 1.124187819 & 14 & 1.159838989 \\
\hline 6 & 7 & 1.068443143 & 12 & 1.105472119 & 10 & 1.112594175 & 8 & 1.152978443 \\
\hline 7 & 13 & 1.067662542 & 15 & 1.089289564 & 7 & 1.091549163 & 13 & 1.115195026 \\
\hline 8 & 18 & 1.033329543 & 8 & 1.086373119 & 4 & 0.998940217 & 11 & 1.05598131 \\
\hline 9 & 16 & 1.012659574 & 18 & 1.019790457 & 17 & 0.99589323 & 15 & 1.002460798 \\
\hline 10 & 15 & 0.990866053 & 6 & 1.017172858 & 9 & 0.964077767 & 18 & 0.994926781 \\
\hline 11 & 1 & 0.917807384 & 13 & 0.972808778 & 14 & 0.945553045 & 4 & 0.951077469 \\
\hline 12 & 3 & 0.908070773 & 7 & 0.899156488 & 1 & 0.934020112 & 17 & 0.923965735 \\
\hline 13 & 2 & 0.869513859 & 1 & 0.892682259 & 6 & 0.922574532 & 12 & 0.898782306 \\
\hline 14 & 4 & 0.869026764 & 3 & 0.892671019 & 13 & 0.915574104 & 1 & 0.870867498 \\
\hline 15 & 6 & 0.851918642 & 4 & 0.879691011 & 2 & 0.894627254 & 5 & 0.862416006 \\
\hline 16 & 10 & 0.80751553 & 5 & 0.834610592 & 16 & 0.872720202 & 2 & 0.811086913 \\
\hline 17 & 5 & 0.802453592 & 2 & 0.82471369 & 3 & 0.866403843 & 6 & 0.805138862 \\
\hline 18 & 17 & 0.792928339 & 10 & 0.793886929 & 5 & 0.840931963 & 3 & 0.795340347 \\
\hline 19 & 19 & 0.792928339 & 19 & 0.760600505 & 19 & 0.724201041 & 19 & 0.655806254 \\
\hline
\end{tabular}

Keterangan : sektor (1) Padi, (2) Tanaman Bahan Makanan, (3) Tanaman Pertanian Lainnya, (4) Peternakan dan Hasil-hasilnya, (5) Kehutanan, (6) Perikanan, (7) Pertambangan dan Penggalian, (8) Industri Makanan, Minuman, dan Tembakau, (9) Industri Lainnya, (10) Pengilangan Minyak Bumi, (11) Listrik, Gas, dan Air Minum, (12) Bangunan/Konstruksi, (13) Perdagangan, (14) Restoran dan Hotel, (15) Pengangkutan dan Komunikasi, (16) Lembaga Keuangan, Usaha Bangunan, dan Jasa Perusahaan, (17) Pemerintahan Umum dan Pertahanan, (18) Jasa-jasa, 19) Kegiatan yang tidak jelas batasnya.

Sumber: data sekunder diolah, 2017 
2010 sektor 8 industri makanan, minuman, dan tembakau menduduki peringkat pertama dengan nilai derajat penyebaran yang lebih kecil dari periode sebelumnya yaitu 1,309497591. Tahun 2015 sektor 7 pertambangan dan penggalian menduduki urutan pertama dengan nilai lebih kecil lagi dibandingkan periode-periode sebelumnya, yaitu 1,258510464 . Sektor 19 menjadi sektor yang paling rendah dalam setiap periodenya dengan nilai yang terus menurun.

11. Keterkaitan Langsung Tidak Langsung Kebelakang Tahun 2000 sampai Tahun 2015
Secara umum, keterkaitan kebelakang langsung tidak langsung atau indices of sensivity of dispertion for forward linkage dari tahun 2000 sampai dengan tahun 2015 akan dipaparkan pada tabel 6 .

Dari tabel 6 terlihat nilai indices of sensivity of dispertion for forward linkage Jawa Timur semakin meningkat dengan sektor yang menduduki peringkat pertama berbeda disetiap tahunnya. Pada tahun 2000 sektor 9 industri lainnya menjadi sektor yang menduduki peringkat pertama dengan nilai derajat kepekaan sebesar 1,926834465 , pada tahun berikutnya sektor 13 perdagangan menduduki peringkat

Tabel 6

Derajat Kepekaan Tahun 2000 sampai Tahun 2015

\begin{tabular}{|c|c|c|c|c|c|c|c|c|}
\hline \multirow{2}{*}{ Ranking } & \multicolumn{8}{|c|}{ Keterkaitan Kedepan Langsung Tidak Langsung } \\
\hline & Sektor & 2000 & Sektor & 2006 & Sektor & 2010 & Sektor & 2015 \\
\hline 1 & 9 & 1.926834465 & 13 & 1.673551563 & 16 & 2.043307244 & 9 & 2.072322327 \\
\hline 2 & 15 & 1.276622317 & 16 & 1.589324942 & 19 & 1.283152408 & 15 & 1.816884127 \\
\hline 3 & 13 & 1.128162008 & 9 & 1.460010107 & 8 & 1.15792097 & 8 & 1.542020661 \\
\hline 4 & 10 & 1.109877455 & 15 & 1.225481255 & 9 & 1.090967996 & 18 & 1.059114599 \\
\hline 5 & 4 & 1.076071438 & 11 & 1.065731863 & 4 & 1.052163954 & 6 & 1.047676978 \\
\hline 6 & 8 & 1.018874107 & 18 & 1.061828051 & 1 & 1.024840716 & 16 & 1.016338848 \\
\hline 7 & 11 & 1.007144279 & 8 & 0.95743881 & 11 & 1.019650408 & 4 & 0.979349154 \\
\hline 8 & 2 & 0.947713837 & 12 & 0.954083466 & 7 & 0.975807872 & 1 & 0.944039534 \\
\hline 9 & 14 & 0.945184252 & 14 & 0.890290975 & 10 & 0.966064566 & 10 & 0.920573426 \\
\hline 10 & 16 & 0.930583493 & 1 & 0.879157294 & 12 & 0.957112737 & 5 & 0.89557007 \\
\hline 11 & 7 & 0.901517836 & 4 & 0.847354632 & 6 & 0.929523494 & 7 & 0.835941665 \\
\hline 12 & 5 & 0.890898277 & 7 & 0.836236592 & 18 & 0.92020183 & 19 & 0.812413411 \\
\hline 13 & 18 & 0.87897878 & 2 & 0.830426202 & 2 & 0.875517018 & 3 & 0.799773108 \\
\hline 14 & 3 & 0.869269233 & 3 & 0.812302942 & 15 & 0.840376982 & 2 & 0.799185581 \\
\hline 15 & 1 & 0.861296489 & 6 & 0.809709844 & 5 & 0.821122222 & 17 & 0.727382901 \\
\hline 16 & 6 & 0.852186719 & 17 & 0.805182005 & 3 & 0.78261932 & 12 & 0.711063944 \\
\hline 17 & 12 & 0.792928339 & 10 & 0.773969088 & 14 & 0.773847527 & 14 & 0.680879067 \\
\hline 18 & 17 & 0.792928339 & 5 & 0.76731986 & 13 & 0.752820228 & 13 & 0.675810487 \\
\hline 19 & 19 & 0.792928339 & 19 & 0.760600505 & 17 & 0.732982508 & 11 & 0.663660112 \\
\hline
\end{tabular}

Keterangan : sektor (1) Padi, (2) Tanaman Bahan Makanan, (3) Tanaman Pertanian Lainnya, (4) Peternakan dan Hasil-hasilnya, (5) Kehutanan, (6) Perikanan, (7) Pertambangan dan Penggalian, (8) Industri Makanan, Minuman, dan Tembakau, (9) Industri Lainnya, (10) Pengilangan Minyak Bumi, (11) Listrik, Gas, dan Air Minum, (12) Bangunan/Konstruksi, (13) Perdagangan, (14) Restoran dan Hotel, (15) Pengangkutan dan Komunikasi, (16) Lembaga Keuangan, Usaha Bangunan, dan Jasa Perusahaan, (17) Pemerintahan Umum dan Pertahanan, (18) Jasa-jasa, 19) Kegiatan yang tidak jelas batasnya.

Sumber: data sekunder diolah, 2017 
pertama dengan nilai derajat kepekaan yang lebih besar dari periode sebelumnya yakni 1,673551563. Tahun 2010 sektor 16 lembaga keuangan, usaha bangunan, dan jasa perusahaan menduduki peringkat pertama dengan nilai derajat kepekaan yang lebih besar dari periode sebelumnya yaitu 2,043307244. Tahun 2015 sektor 9 industri lainnya menduduki urutan pertama dengan nilai lebih besar lagi dibandingkan periode-periode sebelumnya, yaitu 2,072322327 . Sektor yang paling rendah nilai derajat kepekaan mengalami perubahan setiap tahunnya dengan nilai derajat kepekaan yang terus menurun.

\section{Multiplier Product Matrix Tahun 2000}

Multiplier Product Matrix akan menyediakan ukuran kuantitatif atas hubungan antar srektor dalam perekonomian yang disusun berdasarkan hierrarki pada tahun 2000. Semakin tinggi grafik suatu sel akan menunjukkan semakin tinggi pula nilai backward linkage dengan nilai forward linkage. Dari hierarki pada tahun 2000 terlihat nilai MPM berada pada baris 7 dan kolom 9, yakni sektor pertambangan dan penggalian dengan sektor industri lainnya dengan nilai MPM sebesar 0, 1247

Dari gambar 10 terlihat bahwa nilai MPM terendah adalah baris 18 yakni sektor jasa-jasa dan kolom 7 yakni sektor pertambangan dan penggalian, baris 18 yakni sektor jasa-jasa dan kolom 17 yakni sektor pemerintahan umum dan pertahanan, baris 17 yakni sektor pemerintahan umum dan pertahanan dan kolom 12 yakni sektor bangunan/konstruksi, baris 9 yakni industri lainnya dan kolom 19 kegiatan yang tidak jelas batasnya, baris 14 yakni sektor restoran dan hotel dan kolom 12 yakni sektor bangunan/konstruksi, baris 13 yakni sektor perdagangan dan kolom 12 yakni sektor bangunan/konstruksi, bairs 16 yakni sektor lemabaga keuangan, usaha bangunan, dan jasa perusahan dan kolom 12
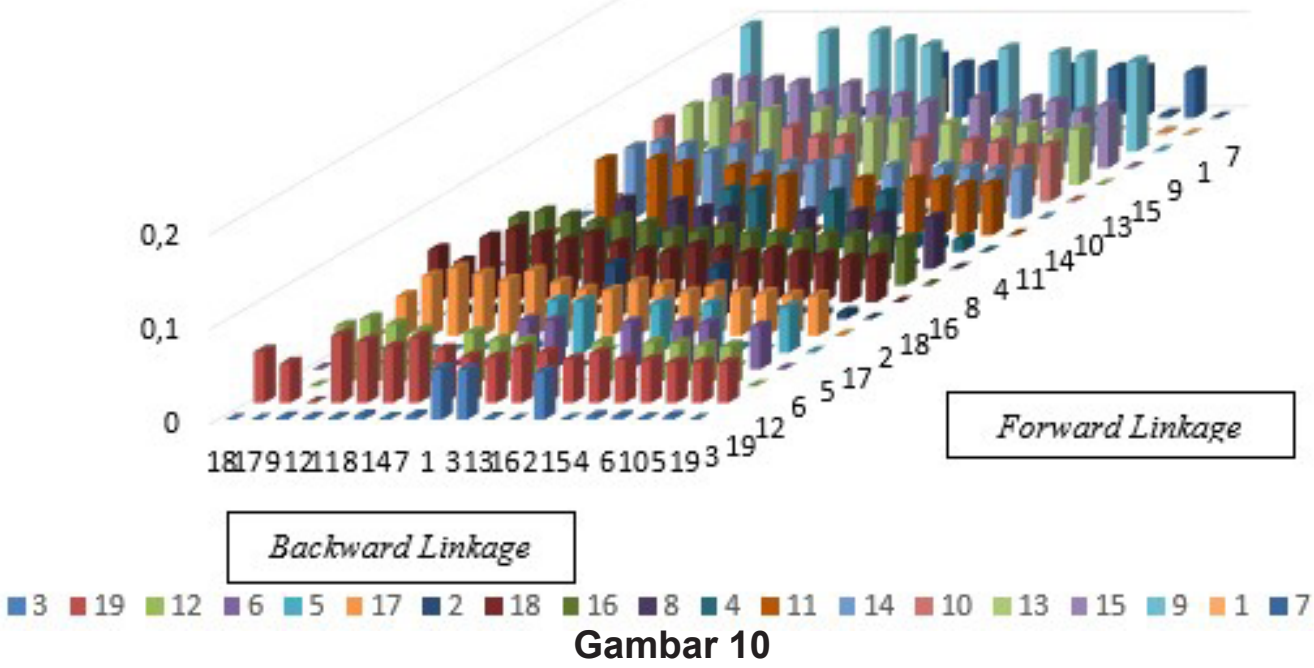

Economic Landscape Jawa Timur Tabel Input-Output Tahun 2000

Keterangan : sektor (1) Padi, (2) Tanaman Bahan Makanan, (3) Tanaman Pertanian Lainnya, (4) Peternakan dan Hasil-hasilnya, (5) Kehutanan, (6) Perikanan, (7) Pertambangan dan Penggalian, (8) Industri Makanan, Minuman, dan Tembakau, (9) Industri Lainnya, (10) Pengilangan Minyak Bumi, (11) Listrik, Gas, dan Air Minum, (12) Bangunan/Konstruksi, (13) Perdagangan, (14) Restoran dan Hotel, (15) Pengangkutan dan Komunikasi, (16) Lembaga Keuangan, Usaha Bangunan, dan Jasa Perusahaan, (17) Pemerintahan Umum dan Pertahanan, (18) Jasa-jasa, 19) Kegiatan yang tidak jelas batasnya.

Sumber: data sekunder diolah, 2017 
yakni sektor bangunan/konstruksi, baris 15 yakni sektor pengangkutan dan komunikasi dan kolom 12 yakni sektor bangunan/ konstruksi, baris 19 yakni sektor kegiatan yang tidak jelas batasnya dan kolom 3 tanaman pertanian lainnya, baris 19 yakni sektor kegiatan yang tidak jelas batasnya dan kolom 12 yakni sektor bangunan/konstruksi, baris 19 yakni sektor kegiatan yang tidak jelas batasnya dan kolom 6 yakni sektor perikanan, baris 19 yakni sektor kegiatan yang tidak jelas batasnya dan kolom 5 yakni sektor kehutanan, baris 19 yakni sektor kegiatan yang tidak jelas batasnya dan kolom 17 yakni sektor pemerintahan umum dan pertahanan, baris 19 yakni sektor kegiatan yang tidak jelas batasnya dan kolom 2 yakni sektor tanaman bahan makanan, baris 19 yakni sektor kegiatan yang tidak jelas batasnya dan kolom 18 yakni sektor jasa-jasa, baris 19 yakni sektor kegiatan yang tidak jelas batasnya dan kolom 16 yakni sektor lembaga keuangan, usaha bangunan, dan jasa perusahaan, baris 19 yakni sektor kegiatan yang tidak jelas batasnya dan kolom 8 yakni sektor industri makanan, minuman, dan tembakau, baris 19 yakni sektor kegiatan yang tidak jelas batasnya dan kolom 4 yakni sektor peternakan dan hasil-hasilnya, baris 19 yakni sektor kegiatan yang tidak jelas batasnya dan kolom 11 yakni sekto listrik, gas, dan air minumr, baris 19 yakni sektor kegiatan yang tidak jelas batasnya dan kolom 14 yakni sektor restoran dan hotel, baris 19 yakni sektor kegiatan yang tidak jelas batasnya dan kolom 10 yakni sektor pengilangan minyak bumi, baris 19 yakni sektor kegiatan yang tidak jelas batasnya dan kolom 13 yakni sektor perdagangan, baris 19 yakni sektor kegiatan yang tidak jelas batasnya dan kolom 15 yakni sektor pengangkutan dan komunikasi, baris 19 yakni sektor kegiatan yang tidak jelas batasnya dan kolom 9 yakni sektor industri lainnya, baris 19 yakni sektor kegiatan yang tidak jelas batasnya dan kolom 1 yakni sektor padi, baris 19 yakni sektor kegiatan yang tidak jelas batasnya dan kolom 7 yakni sektor pertambangan dan penggalian, dengan nilai terendah yakni 0 , artinya tidak memiliki keterkaitan baik keterkaitan kedepan maupun keterkaitan kebelakang.

\section{Multiplier Product Matrix Tahun 2006}

Dari hierarki pada tahun 2006 terlihat bahwa terjadi perubahan struktur perekonomian di Jawa Timur yang di indikasikan dengan berubahnya nilai MPM 2006 yang tidak lagi sama dan sebangun dengan MPM Tahun 2000. Gambar 11 menunjukkan terjadinya perubahan yang mana sektor yang mendominasi keterkaitan ada pada tahun 2006 tidak lagi sama dengan periode sebelumnya. Pada tahun 2000 yang memiliki MPM tertinggi adalah baris 7 dan kolom 9 sebesar 0,1247 , sedangakn pada tahun 2006 yang memiliki nilai MPM tertinggi adalah baris 6 kolom 13 yakni sektor perikanan dengan sektor perdagangan dengan nilai multiplier sebesar 0,11012 lebih rendah dari tahun 2000. makanan, baris 19 yakni sektor kegiatan yang tidak jelas batasnya dan kolom 18 yakni sektor jasa-jasa, baris 19 yakni sektor kegiatan yang tidak jelas batasnya dan kolom 16 yakni sektor lembaga keuangan, usaha bangunan, dan jasa perusahaan, baris 19 yakni sektor kegiatan yang tidak jelas batasnya dan kolom 8 yakni sektor industri makanan, minuman, dan tembakau, baris 19 yakni sektor kegiatan yang tidak jelas batasnya dan kolom 4 yakni sektor peternakan dan hasil-hasilnya

Sektor yang tidak memiliki nilai keterkaitan sama sekali pada tahun 2006 adalah baris 9 yakni sektor indsutri lainnya dan kolom 19 yakni sektor kegiatan yang tidak jelas batasnya, baris 19 yakni sektor kegiatan yang tidak jelas batasnya dan kolom 3 tanaman pertanian lainnya, baris 19 yakni sektor kegiatan yang tidak jelas batasnya dan kolom 12 yakni sektor bangunan/konstruksi, baris 19 yakni sektor kegiatan yang tidak jelas batasnya dan kolom 6 yakni sektor perikanan, baris 19 yak- 


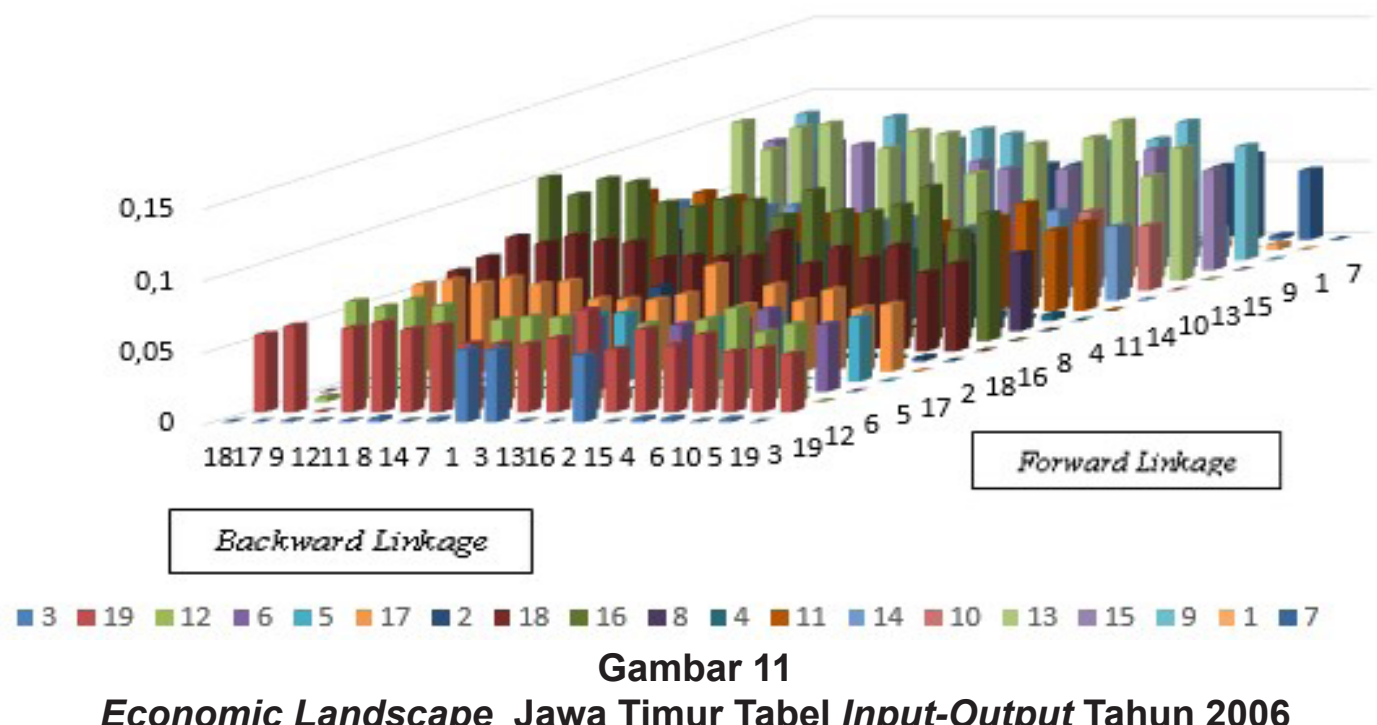

Keterangan : sektor (1) Padi, (2) Tanaman Bahan Makanan, (3) Tanaman Pertanian Lainnya, (4) Peternakan dan Hasil-hasilnya, (5) Kehutanan, (6) Perikanan, (7) Pertambangan dan Penggalian, (8) Industri Makanan, Minuman, dan Tembakau, (9) Industri Lainnya, (10) Pengilangan Minyak Bumi, (11) Listrik, Gas, dan Air Minum, (12) Bangunan/Konstruksi, (13) Perdagangan, (14) Restoran dan Hotel, (15) Pengangkutan dan Komunikasi, (16) Lembaga Keuangan, Usaha Bangunan, dan Jasa Perusahaan, (17) Pemerintahan Umum dan Pertahanan, (18) Jasa-jasa, 19) Kegiatan yang tidak jelas batasnya.

Sumber: data sekunder diolah, 2017

ni sektor kegiatan yang tidak jelas batasnya dan kolom 5 yakni sektor kehutanan, baris 19 yakni sektor kegiatan yang tidak jelas batasnya dan kolom 17 yakni sektor pemerintahan umum dan pertahanan, baris 19 yakni sektor kegiatan yang tidak jelas batasnya dan kolom 2 yakni sektor tanaman bahan, baris 19 yakni sektor kegiatan yang tidak jelas batasnya dan kolom 11 yakni sekto listrik, gas, dan air minum, baris 19 yakni sektor kegiatan yang tidak jelas batasnya dan kolom 14 yakni sektor restoran dan hotel, baris 19 yakni sektor kegiatan yang tidak jelas batasnya dan kolom 10 yakni sektor pengilangan minyak bumi, baris 19 yakni sektor kegiatan yang tidak jelas batasnya dan kolom 13 yakni sektor perdagangan, baris 19 yakni sektor kegiatan yang tidak jelas batasnya dan kolom 15 yakni sektorpengangkutan dan komunikasi, baris 19 yakni sektor kegiatan yang tidak jelas batasnya dan kolom 9 yakni sektor industri lainnya, baris
19 yakni sektor kegiatan yang tidak jelas batasnya dan kolom 1 yakni sektor padi, baris 19 yakni sektor kegiatan yang tidak jelas batasnya dan kolom 7 yakni sektor pertambangan dan penggalian, dengan nilai terendah yakni 0 , artinya tidak memiliki keterkaitan baik keterkaitan kedepan maupun keterkaitan kebelakang.

\section{Multiplier Product Matrix Tahun 2010}

Dari hierarki pada tahun 2010 terlihat bahwa terjadi perubahan struktur perekonomian di Jawa Timur yang di indikasikan dengan berubahnya nilai MPM 2010 yang tidak lagi sama dan sebangun dengan MPM Tahun 2000 dan Tahun 2006. Tahun 2010 sektor yang memiliki nilai MPM tertinggi adalah baris 4 dan kolom 16 yakni sektor peternakan dan hasil-hasilnya dengan sektor lembaga keuangan, usaha bangunan, dan jasa perusahaan dengan nilai multiplier 0,141735 lebih tinggi dari tahun 2000 dan tahun 2006. 


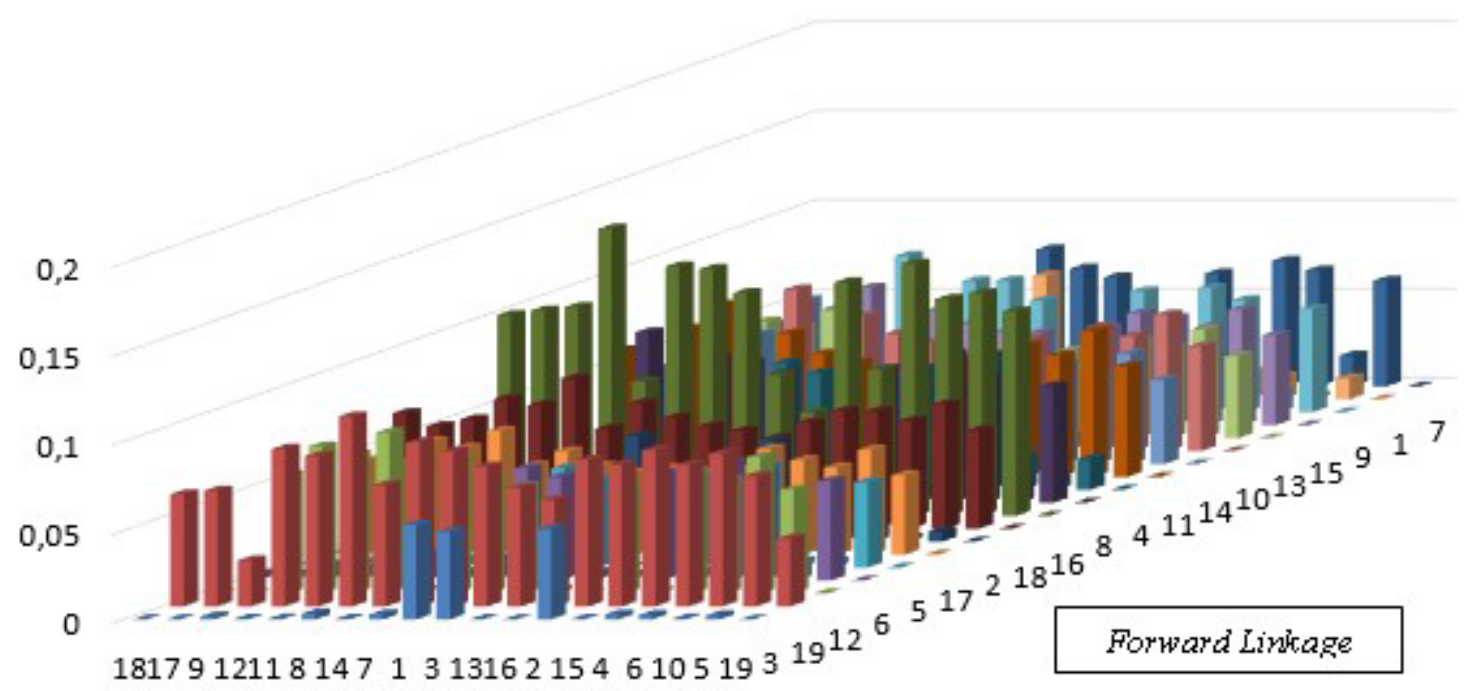

Backward Linkage

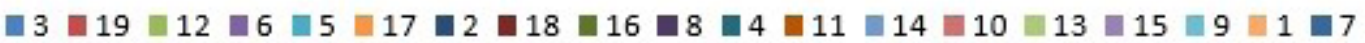

\section{Gambar 12}

Economic Landscape Jawa Timur Tabel Input-Output Tahun 2010

Keterangan : sektor (1) Padi, (2) Tanaman Bahan Makanan, (3) Tanaman Pertanian Lainnya, (4) Peternakan dan Hasil-hasilnya, (5) Kehutanan, (6) Perikanan, (7) Pertambangan dan Penggalian, (8) Industri Makanan, Minuman, dan Tembakau, (9) Industri Lainnya, (10) Pengilangan Minyak Bumi, (11) Listrik, Gas, dan Air Minum, (12) Bangunan/Konstruksi, (13) Perdagangan, (14) Restoran dan Hotel, (15) Pengangkutan dan Komunikasi, (16) Lembaga Keuangan, Usaha Bangunan, dan Jasa Perusahaan, (17) Pemerintahan Umum dan Pertahanan, (18) Jasa-jasa, 19) Kegiatan yang tidak jelas batasnya.

Sumber: data sekunder diolah, 2017

Tahun 2010 sektor yang memiliki nilai MPM tertinggi adalah baris 4 dan kolom 16 yakni sektor peternakan dan hasil-hasilnya dengan sektor lembaga keuangan, usaha bangunan, dan jasa perusahaan dengan nilai multiplier 0,141735 lebih tinggi dari tahun 2000 dan tahun 2006.

Gambar 12 menunjukkan terjadinya perubahan yang mana sektor yang mendominasi keterkaitan pada tahun 2010 tidak lagi sama dengan dua periode sebelumnya. Pada tahun 2000 yang memiliki MPM tertinggi adalah baris 7 dan kolom 9 sebesar 0,1247 , sedangakn pada tahun 2006 yang memiliki nilai MPM tertinggi adalah baris 6 kolom 13 sebesar 0,11012 lebih rendah dari tahun 2000.
Baris 19 yakni sektor kegiatan yang tidak jelas batasnya dan kolom 3 tanaman pertanian lainnya, baris 19 yakni sektor kegiatan yang tidak jelas batasnya dan kolom 12 yakni sektor bangunan/konstruksi, baris 19 yakni sektor kegiatan yang tidak jelas batasnya dan kolom 6 yakni sektor perikanan, baris 19 yakni sektor kegiatan yang tidak jelas batasnya dan kolom 5 yakni sektor kehutanan, baris 19 yakni sektor kegiatan yang tidak jelas batasnya dan kolom 17 yakni sektor pemerintahan umum dan pertahanan, baris 19 yakni sektor kegiatan yang tidak jelas batasnya dan kolom 2 yakni sektor tanaman bahan makanan, baris 19 yakni sektor kegiatan yang tidak jelas batasnya dan kolom 18 yakni sektor jasa-jasa, baris 19 yakni sektor kegiatan yang tidak jelas batasnya dan 
kolom 16 yakni sektor lembaga keuangan, usaha bangunan, dan jasa perusahaan, baris 19 yakni sektor kegiatan yang tidak jelas batasnya dan kolom 8 yakni sektor industri makanan, minuman, dan tembakau, baris 19 yakni sektor kegiatan yang tidak jelas batasnya dan kolom 4 yakni sektor peternakan dan hasil-hasilnya, baris 19 yakni sektor kegiatan yang tidak jelas batasnya dan kolom 11 yakni sektor listrik, gas, dan air minumr, baris 19 yakni sektor kegiatan yang tidak jelas batasnya dan kolom 14 yakni sektor restoran dan hotel, baris 19 yakni sektor kegiatan yang tidak jelas batasnya dan kolom 10 yakni sektor pengilangan minyak bumi, baris 19 yakni sektor kegiatan yang tidak jelas batasnya dan kolom 13 yakni sektor perdagangan, baris 19 yakni sektor kegiatan yang tidak jelas batasnya dan kolom 15 yakni sektorpengangkutan dan komunikasi, baris 19 yakni sektor kegiatan yang tidak jelas batasnya dan kolom 9 yakni sektor industri lainnya, baris 19 yakni sektor kegiatan yang tidak jelas batasnya dan kolom 1 yakni sektor padi, baris 19 yakni sektor kegiatan yang tidak jelas batasnya dan kolom 7 yakni sektor pertambangan dan penggalian, dengan nilai terendah yakni 0 , artinya tidak memiliki keterkaitan baik keterkaitan kedepan maupun keterkaitan kebelakang.

\section{Multiplier Product Matrix Tahun 2015}

Dari hierarki pada tahun 2015 terlihat bahwa terjadi perubahan struktur perekonomian di Jawa Timur yang di indikasikan dengan berubahnya nilai MPM 2015 yang tidak lagi sama dan sebangun dengan MPM Tahun 2006 dan Tahun 2010 tetapi sebangun dengan MPM tahun 2000. Gambar 13 menunjukkan terjadinya perubahan yang mana sektor yang mendominasi keterkaitan pada tahun 2015.

Pada tahun 2000 yang memiliki MPM tertinggi adalah baris 7 dan kolom 9 sebesar 0,1247 , sedangakn pada tahun 2006 yang memiliki nilai MPM tertinggi adalah baris 6 kolom 13 sebesar 0,11012 lebih rendah dari tahun 2000. Tahun 2010 sektor yang memiliki nilai MPM tertinggi adalah baris 4 dan kolom 16 dengan nilai MPM 0,141735. Tahun 2015 yang menduduki nilai MPM tertinggi adalah baris 7 dan kolom 9 seperti halnya tahun 2000 yakni sektor pertambangan dan penggalian dengan sektor industri lainnya dengan nilai MPM sebesar 0,19426 yang jauh lebih tinggi dibanding tiga periode sebelumnya. Sektor yang tidak memiliki nilai keterkaitan sama sekali pada tahun 2006 adalah baris 19 yakni sektor kegiatan yang tidak jelas batasnya dan kolom 3 tanaman pertanian lainnya, baris 19 yakni sektor kegiatan yang tidak jelas batasnya dan kolom 12 yakni sektor bangunan/konstruksi, baris 19 yakni sektor kegiatan yang tidak jelas batasnya dan kolom 6 yakni sektor perikanan, baris 19 yakni sektor kegiatan yang tidak jelas batasnya dan kolom 5 yakni sektor kehutanan, baris 19 yakni sektor kegiatan yang tidak jelas batasnya dan kolom 17 yakni sektor pemerintahan umum dan pertahanan, baris 19 yakni sektor kegiatan yang tidak jelas batasnya dan kolom 2 yakni sektor tanaman bahan makanan, baris 19 yakni sektor kegiatan yang tidak jelas batasnya dan kolom 18 yakni sektor jasa-jasa, baris 19 yakni sektor kegiatan yang tidak jelas batasnya dan kolom 16 yakni sektor lembaga keuangan, usaha bangunan, dan jasa perusahaan, baris 19 yakni sektor kegiatan yang tidak jelas batasnya dan kolom 8 yakni sektor industri makanan, minuman, dan tembakau, baris 19 yakni sektor kegiatan yang tidak jelas batasnya dan kolom 4 yakni sektor peternakan dan hasil-hasilnya, baris 19 yakni sektor kegiatan yang tidak jelas batasnya dan kolom 11 yakni sekto listrik, gas, dan air minumr, baris 19 yakni sektor kegiatan yang tidak jelas batasnya dan kolom 14 yakni sektor restoran dan hotel, baris 19 yakni sektor kegiatan yang tidak jelas batasnya dan kolom 10 yakni sektor pengilangan minyak bumi, baris 19 yakni sek- 


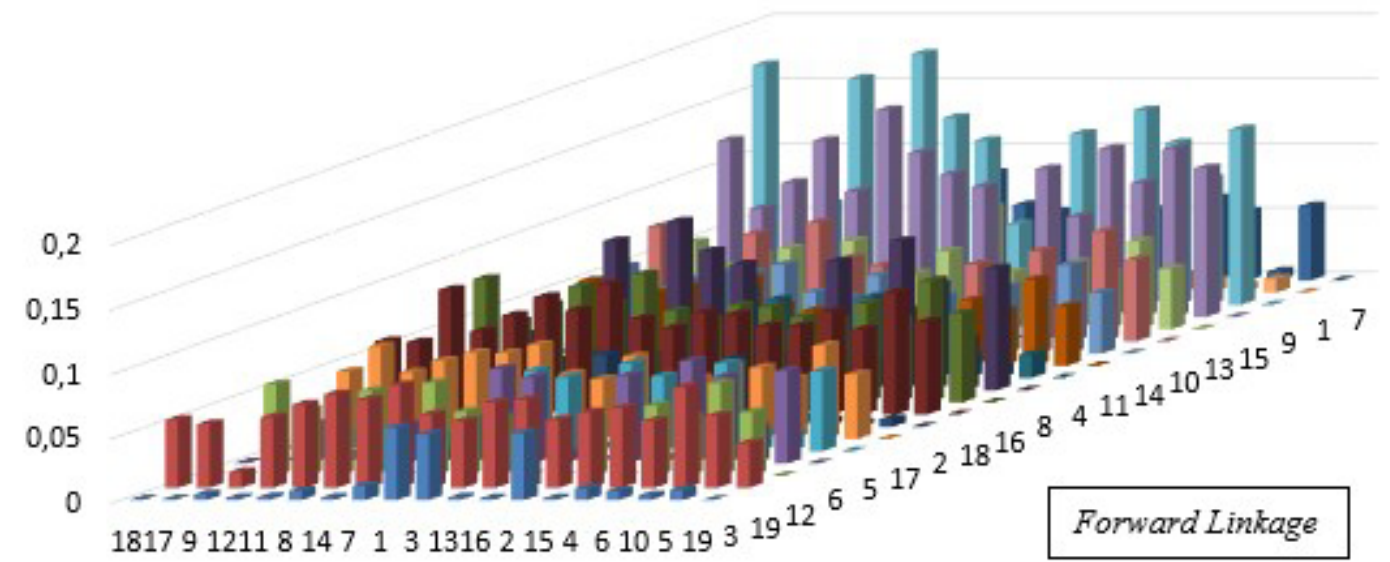

Backward Linkage

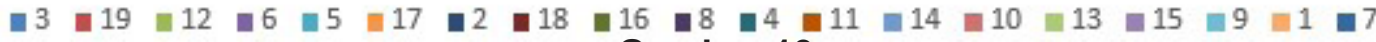

\section{Gambar 13}

Economic Landscape Jawa Timur Tabel Input-Output Tahun 2015

Keterangan : sektor (1) Padi, (2) Tanaman Bahan Makanan, (3) Tanaman Pertanian Lainnya, (4) Peternakan dan Hasil-hasilnya, (5) Kehutanan, (6) Perikanan, (7) Pertambangan dan Penggalian, (8) Industri Makanan, Minuman, dan Tembakau, (9) Industri Lainnya, (10) Pengilangan Minyak Bumi, (11) Listrik, Gas, dan Air Minum, (12) Bangunan/Konstruksi, (13) Perdagangan, (14) Restoran dan Hotel, (15) Pengangkutan dan Komunikasi, (16) Lembaga Keuangan, Usaha Bangunan, dan Jasa Perusahaan, (17) Pemerintahan Umum dan Pertahanan, (18) Jasa-jasa, 19) Kegiatan yang tidak jelas batasnya.

Sumber: data sekunder diolah, 2017

tor kegiatan yang tidak jelas batasnya dan kolom 13 yakni sektor perdagangan, baris 19 yakni sektor kegiatan yang tidak jelas batasnya dan kolom 15 yakni sektor pengangkutan dan komunikasi, baris 19 yakni sektor kegiatan yang tidak jelas batasnya dan kolom 9 yakni sektor industri lainnya, baris 19 yakni sektor kegiatan yang tidak jelas batasnya dan kolom 1 yakni sektor padi, baris 19 yakni sektor kegiatan yang tidak jelas batasnya dan kolom 7 yakni sektor pertambangan dan penggalian, dengan nilai terendah yakni 0 , artinya tidak memiliki keterkaitan baik keterkaitan kedepan maupun keterkaitan kebelakang.

16. Dampak Permintaan Akhir Terhadap Output

Untuk mengetahui dampak permintaan akhir terhadap output, yang perlu di lakukan adalah mengalikan matriks leontif inverse dengan tabel nilai tambah bruto pada tabel dasar input-output. Intepretasi yang dilakukan dapat diintepretasikan secara baris maupun secara kolom. Secara baris artinya output sektor $x$ yang terbentuk sebagai akibat kode 301 sampai dengan kode 305 . Jumlah secara baris menujukkan total output untuk sektor $\mathrm{x}$ tersebut. Sedangkan secara kolom menunjukkan suatu pengaruh komponen akhir terhadap pembentukan masing-masing sektor. Misal kode 301 mengakibatkan pembentukan output sektor 1 sampai dengan sektor 19 . Jumlah kolom 301 menunjukkan besarnya seluruh sektor perekonomian yang terbentuk sebagai akibat dari konsumsi rumah tangga.

Jika diintreperetasikant secara baris, maka sektor 1 yakni sektor padi terbentuk dari sektor 301 yakni konsumsi 
rumah tangga sebesar 1275836,82 ; sektor 302 yakni konsumsi pemerintah sebesar 3906,01; sektor 303 yakni pembentukan modal tetap bruto sebesar 4351,41 ; sektor 304 yakni perubahan stok sebesar 5764477,40; sektor 305 yakni ekspor barang danjasaluarnegerisebesar418301,76 ; sektor 307 ekspor barang dan jasa antar provinsi sebesar 2932786,45. Begitupula untuk intrepretasi sektor dua sampai dengan sektor 19 secara baris. Interpretasi secara kolom menunjukkan pengaruh pada kolom yang ada, missal kolom 301 yakni konsumsi rumah tangga mengakibatkan pembentukan output pada sektor 1 yakni padi sebesar 1275836.828; sektor 2 yakni tanaman bahan makanan sebesar 10438436.3; sektor 3 yakni tanaman pertanian lainnya sebesar 5270037.314; sektor 4 yakni peternakan dan hasil-hasilnya sebesar 11577837.64; sektor 5 yakni kehutanan sebesar 993665.1541; sektor 6 yakni perikanan sebesar 4016456.509; sektor 7 yakni pertambangan dan penggalian sebesar 580436.5034; sektor 8 yakni industri makanan, minuman, dan tembakau sebesar 32882827.39; sektor 9 yakni industri lainnya sebesar 29954263.45; sektor 10 yakni pengilangan minyak sebesar 2726724.097; sektor 11 yakni listrik, gas, dan air minum sebesar 3158772.739; sektor 12 yakni bangunan/konstruksi sebesar 1272960; sektor 13 yakni perdagangan sebesar 16110547.78; sektor 14 yakni restoran dan hotel sebesar 14751993.54 ; sektor 15 yakni pengangkutan dan komunikasi sebesar 8411638.893; sektor 16 yakni lembaga keuangan, usaha bangunan, dan jasa perusahaan sebesar 6547441.105; sektor 17 yakni pemerintahan umum dan pertanahan sebesar 0 ; sektor 18 yakni jasa-jasa sebesar 7986605.284; sektor 19 yakni sektor kegiatan yang tidak jelas batasnya sebesar 0 . Jumlah secara kolom yakni sebesar 157956480.6 menunjukkan besarnya seluruh sektor perekonomian yang terbentuk sebagai akibat dari konsumsi rumah tangga. Begitu pula untuk tahun selanjurnya dilakukan intrepretasi yang sama.

\section{Dampak Permintaan Akhir Terhadap Nilai Tambah Bruto \\ Untuk mengetahui dampak per-} mintaan akhir terhadap nilai tambah bruto, yang perlu dilakukan adalah mengalikan matriks dampak permintaan akhir terhadap output dengan tabel matriks koefisien nilai tambah bruto. Intepretasi yang dilakukan dapat diintepretasikan secara baris maupun secara kolom. Secara baris artinya output sektor $\mathrm{x}$ yang terbentuk sebagai akibat dari komposisi nilai tambah bruto dalam hal ini tersusun dari kode 301 sampai dengan kode 305 . Jumlah secara baris menujukkan total nilai tambah bruto untuk sektor $x$ tersebut. Sedangkan secara kolom menunjukkan pengaruh suatu komponen permintaan akhit terhadap penciptaan nilai tambah bruto. Jumlah kolom menunjukkan besarnya nilai tambah bruto seluruh perekonomian sebagai akibat konsumsi dari kode pada kolom.

Jika diintreperetasikant secara baris, maka sektor (1) yakni sektor padi terbentuk sebagai akibat dari nilai tambah bruto dari sektor (301) yakni konsumsi rumah tangga sebesar 1129064.55; sektor (302) yakni konsumsi pemerintah sebesar 3456.66918; sektor (303) yakni pembentukan modal tetap bruto sebesar 3850.82805; sektor (304) yakni perubahan stok sebesar 5101331.86; sektor (305) yakni ekspor barang dan jasa luar negeri sebesar 370180.324 ; sektor (307) ekspor barang dan jasa antar provinsi sebesar 2595398.67. Begitupula untuk intrepretasi sektor dua sampai dengan sektor 19 secara baris. Interpretasi secara kolom menunjukkan pengaruh suatu komponen permintaan akhit terhadap penciptaan nilai tambah bruto missal kolom 301 yakni konsumsi rumah tangga mengakibatkan pembentukan output pada sektor 1 yakni padi sebesar 1129064.55; sektor 2 yakni tanaman bahan makanan sebesar 
9655171.53; sektor 3 yakni tanaman pertanian lainnya sebesar 4708356.18; sektor 4 yakni peternakan dan hasil-hasilnya sebesar 10702073.4; sektor 5 yakni kehutanan sebesar 983749.647; sektor 6 yakni perikanan sebesar 3789957.06 ; sektor 7 yakni pertambangan dan penggalian sebesar 429262.727; sektor 8 yakni industri makanan, minuman, dan tembakau sebesar 22628128.7; sektor 9 yakni industri lainnya sebesar 18549593.6; sektor 10 yakni pngilangan minyak sebesar 2689687.58; sektor 11 yakni listrik, gas, dan air minum sebesar 1860786.03; sektor 12 yakni bangunan/konstruksi sebesar 646663.761; sektor 13 yakni perdagangan sebesar 12075893.4; sektor 14 yakni restoran dan hotel sebesar 6806994.23; sektor 15 yakni pengangkutan dan komunikasi sebesar 6665214.59; sektor 16 yakni lembaga keuangan, usaha bangunan, dan jasa perusahaan sebesar 5301613,37; sektor 17 yakni pemerintahan umum dan pertanahan sebesar 0 ; sektor 18 yakni jasa-jasa sebesar 6221417,59; sektor 19 yakni sektor kegiatan yang tidak jelas batasnya sebesar 0 . Jumlah secara kolom yakni sebesar 114843628 menunjukkan besarnya nilai tambah bruto seluruh perekonomian sebagai akibat konsumsi dari konsumsi rumah tangga. Begitu pula untuk tahun selanjurnya dilakukan intrepretasi yang sama.

\section{Pembahasan}

Transformasi struktural telah terjadi di Jawa Timur. Dominasi sektor sekunder dan sektor tersier pada economic landscape memberikan bukti telah terjadi perubahan struktur ekonomi. Nilai keterkaitan antar sektor ekonomi juga di pimpin oleh sektor sekunder dan sektor tersier. Selama periode penelitian, peneliti melihat adanya perubahan economic landscape dari sektor yang berbeda namun masih tergolong dalam sektor sekunder dan sektor tersier.

Pada tahun 2000 yang menjadi nilai tertinggi dari MPM Jawa Timur adalah sektor dengan baris 7 dan kolom 9 yakni sektor pertambangan dan penggalian dengan sektor industri lainnya dengan nilai MPM sebesar 0,1247.

Periode selanjutnya, yakni tahun 2006 kolom dan baris penyusun MPM berbeda dengan periode sebelumnya, yakni baris 6 dan kolom 13 yakni sektor perikanan dengan sektor perdagangan dengan nilai MPM sebesar 0,11012

Tahun 2010, yakni periode ketiga penelitian sektor yang memiliki nilai MPM tertinggi adalah baris 4 dan kolom 16 yakni sektor peternakan dengan sektor lembaga keuangan, usaha bangunan, dan jasa perusahaan dengan nilai MPM 0,141735.

Pada akhir periode penelitian, yakni tahun 2015 yang menduduki nilai MPM tertinggi adalah baris 7 dan kolom 9 seperti halnya tahun 2000 yakni sektor pertambangan dan penggalian dengan sektor industri lainnya dengan nilai MPM sebesar 0,19426. Nilai MPM tahun 2015 merupakan nilai tertinggi sepanjang periode penelitian.

Secara teoritis, pertumbuhan ekonomi yang terjadi pada suatu negara akan melibatkan perubahan struktur perekonomian di negara tersebut (Amir dan Nazara, 2005) yang dapat dilihat dari nilai Multiplier Product Matrix (MPM) (Borges and Montibeler, 2014); (Szirmai, 2012).

Dilihat dari nilai keterkaitan langsung secara kebelakang, dominasi urutan penyumbang keterkaitan langsung tertinggi didominasi oleh sektor sekunder dan tersier yang tercermin pada table 3. Dari perhitungan nilai keterkaitan langsung kedepan yang terlihat pada tabel 4 . sekunder dan sektor tersier juga mendominasi peringkat atas hasil perhitungan. Menurut aliran klasik Adam Smith, tahap terkahir dari transformasi struktural adalah dominasi sektor manufaktur dan mulai ditinggalkannya sektor tersier. Hal ini sejalan yang terjadi pada struktur perekonomian Jawa Timur.

Perubahan yang terjadi di Jawa Timur ini berkaitan dengan kebijakan yang 
dilakukan oleh pemerintah di level nasional yakni paska terjadinya krisis ekonomi tahun 1998 yang dialami Indonesia. Salah satu langkah yang dilakukan oleh pemerintah Indonesia dalam menangani krisis 1998 adalah dengan menggandeng International Monetary Fund (IMF) (Karmeli dan Fatimah, 2008). Ada banyak formulasi yang ditawarkan oleh IMF untuk mempercepat recovery Indonesia, salah satu saran dari IMF yang memiliki korelasi positif dengan perubahan struktur perekonomian Jawa Timur adalah penekanan terhadap perubahan struktur perekonomian di Indonesia dan dominasi oleh sektor swasta (Tarmidi, 1999); (Nematnejad, 2000).

Sebagai dampak dari kebijakan perubahan struktur ekonomi tersebut, perubahan yang terjadi dapat dilihat dari kecepatan industrialisasi yang terjadi di berbagai wilayah di Indonesia. Salah satu parameter yang digunakan untuk melihat dominasi peran swasta tersenut adalah perankingan oleh Asia Competitivness Institute (ACI). Pada November 2017 Jawa Timur menduduki peringkat pertama kategori Easy of Doing Business (EDB) naik dua level dibandingkan periode penilaian sebelumnya. Artinya, industrialisasi yang terjadi di Jawa Timur sangat dominan yang menyebabkan perubahan struktur perekonomian kearah sektor sekunder dan sektor tersier. Keadaan diatas searah dengan penelitian yang dilakukan oleh Andriansyah bahwa selama periode 2006 sampai 2010 di Jawa Timur terjadi perubahan struktur perekonomian yang dicerminkan dari visualisasi economic landscape yang mendominasi adalah sektor 3 yakni industri pengolahan, sektor 6 yakni perdagangan, hotel, dan restoran, sektor 8 yakni keuangan, persewaan, dan jasa perusahaan, sektor 7 yakni pengangkutan dan komunikasi.

Hasil Perhitungan daya penyebaran yang tercermin dalam tabel 5 dan perhitungan derajat kepekaan yang tercermin dalam tabel 6 memperlihatkan ter- jadi dominasi sektor sekunder dan sektor tersier sejalan dengan hasil perhitungan keterkaitan langsung. Ini mendukung teori industrialisasi yang digagas oleh Lewi's. Dengan adanya dominasi di sektor sekunder dan sektor tersier memperlihatkan di Jawa Timur terjadi industrialisasi selama periode penelitian dan nantinya akan berdampak pada transfer tenaga kerja dari sektor tradisional ke sektor modern dengan berbagai asumsi yang di bangun oleh Arthur Lewis. Industrialisasi akan memberikan dampak pula terhadap perpindahan tenaga kerja dari sektor yang memiliki produktivitas rendah atau lebih dikenal sebagai sektor tradisional atau sektor pertanian kepada sektor yang memiliki produktivitas tinggi yang biasa diidentikan dengan sektor tersier dan sektor sekunder (Rodrik, 2013) yang ditandai dengan meningkatnya kontrinbusi sektor tersier terhadap PDRB hingga $70 \%$ terhadap PDB (Szirman, 2012). Untuk PDRB Jawa Timur, terjadi dominasi pada sektor tersier diawal peneltian sebesar $42,8 \%$ terhadap PDRB meningkat hingga $54,5 \%$. Artinya separuh lebih PDRB Jawa Timur di dominasi oleh kegiatan pada sektor tersier. Angka ini memang belum sampai $70 \%$ sesuai dengan penelitian yang dilakukan Szirman, akan tetapi jika ditambah dengan sektor sekunder, akan menjadi $80 \%$ dominasi terhadap PDRB. Sektor pertanian, kontribusinya terus mengalami penurunan seiring dengan periode penelitian, yang bias diindikasikan bahwa sektor ini mulai ditinggalkan oleh masyarakat, atau peningkatan disektor primer dan sektor tersier jauh lebih besar dibandingkan dengan sektor primer.

Dengan demikian, setelah goncangan pada internal suatu negara akan berpengaruh pada formulasi kebijakan yang akan diterapkan yang nantinya akan berimplikasi pada kebijakan yang ada di berbagai wilayah yang ada pada negara tersebut. Perubahan struktur ekonomi di Jawa Timur terjadi sebagai akibat kebijakan setelah krisis 1998 yang memberi- 
kan dampak terjadinya industrialisasi dan dominasi oleh sektor sekunder dan sektor tersier dalam perekonomian.

\section{Simpulan}

Berdasarkan hasil analisis data dan pembahasan yang telah diuraikan maka dapat disimpulkan pattern of economic landscape Jawa Timur dapat dilihat dari hasil analisis keterkaitan langsung, keterkaitan langsung tidak langsung, dan perhitungan multiplier product matrix. Hasil analisis keterkaitan langusng, untuk keterkaitan langsung kebelakang sektor yang memiliki nilai keterkaitan tertinggi pada tahun 2000 adalah sektor 14 yakni restoran dan hotel dengan nilai 0,53857123 , tahun 2006 sektor 16 yakni lembaga keuangan, usaha bangunan, dan jasa perusahaan dengan nilai 0,48473649, tahun 2010 sektor 8 yakni industri makanan, minuman, dan tembakau dengan nilai 0,567629796, tahun 2015 sektor 10 yakni pengilangan minyak bumi dengan nilai 0,61762626. Sektor yang memiliki nilai keterkaitan langsung kedepan yang tertinggi pada tahun 2000 adalah sektor 9 yakni industri lainnya dengan nilai 1,049444856, tahun 2006 sektor 13 yakni perdagangan dengan nilai 0,894239553, tahun 2010 sektor 16 yakni lembaga keuangan, usaha bangunan, dan jasa perusahaan dengan nilai 1,34996574, tahun 2015 sektor 9 yakni industri lainnya dengan nilai 1,2836834.

Hasil analisis keterkaitan langsung tidak langsung, untuk keterkaitan langsung tidak langsung kebelakang yang memiliki nilai tertinggi tahun 2000 adalah sektor 12 yakni bangunan/konstruksi dengan nilai 1,356850291, tahun 2006 sektor 16 yakni lembaga keuangan, usaha bangunan, dan jasa perusahaan dengan nilai 1,344209424, tahun 2010 sektor 8 yakni industi makanan, minuman, dan tembakau dengan nilai 1,309497591, tahun 2015 sektor 7 yakni pertambangan dan penggalian dengan nilai 1,258510464. Keterkaitan langsung tidak langsung kedepan yang memiliki nilai tertinggi tahun 2000 adalah sektor 9 yakni industri lainnya dengan nilai 1,926834465. Tahun 2006 sektor 13 yakni perdagangan dengan nilai 1,673551563. Tahun 2010 sektor 16 yakni lembaga keuangan, usaha bangunan, dan jasa perusahaan dengan nilai 2,043307244.

Tahun 2016 sektor 9 yakni yakni industri lainnya dengan nilai 2,072322327. Terjadi perubahan struktur di Jawa Timur selama periode 2000 hingga 2015 yang ditunjukkan dengan perubahan economic landscape. Perubahan ini dapat dilihat pada perubahan MPM. Tahun 2000 nilai MPM tertinggi adalah Tahun 2000 nilai MPM tertinggi adalah sektor dengan baris 7 dan kolom 9 yakni sektor pertambangan dan penggalian dengan sektor industri lainnya dengan nilai MPM sebesar 0,1247. Tahun 2006 nilai MPM tertinggi adalah baris 6 dan kolom 13 yakni sektor perikanan dengan sektor perdagangan dengan nilai MPM sebesar 0,11012. Tahun 2010 nilai MPM tertinggi adalah baris 4 dan kolom 16 yakni sektor peternakan dengan sektor lembaga keuangan, usaha bangunan, dan jasa perusahaan dengan nilai MPM 0,141735 . Tahun 2015 nilai MPM tertinggi adalah baris 7 dan kolom 9 seperti halnya tahun 2000 yakni sektor pertambangan dan penggalian dengan sektor industri lainnya dengan nilai MPM sebesar 0,19426

\section{Daftar Pustaka}

Amir, Hidayat dan Suahasil Nazara. 2005. Analisis Perubahan Struktur Ekonomi Jawa Timur (Economic Landscape) dan Kebijakan Strategi Pembangunan Jawa Timur Tahun 1994 dan 2000 : Analisis Input-Output. Jurnal Ekonomi dan Pembangunan Indonesia. Vol. V (02) : 37-55.

Badan Pusat Statistik Jawa Timur.

D'Hernoncourt, J., M. Codier, and D. Hadley. 2011. "Input-Output Multiplier Spesification Sheet and Supporting Material". Science Policy Integartion For Coastal 
System Assesment.

Guilhoto, J.J.M., Michael Sonis and Geoffrey J.D. Hewings. 1999. "Multiplier Product Matrix Analysis For Interregional InputOutput Systems: An Application To The Brazilian Economy". Munich Personal RePEc Archive Paper No. 54671.

Karmeli, Elly dan Siti Fatimah. 2008. Krisis Ekonomi Indonesia. Journal of Indonesian Applied Economics Vol. 2 (2) : 164-173.

Leontif, Wassily. 1986. "Input-Output Economics". Oxford : Oxford University Press

Nassif, Andre, Carmem Feijo and Eliane Araujo. 2013. "Structural Change And Economic Development : Is Brazil Catching Up Or Falling Behind?". UNCTAD Discussion Paper.

Nematnejad, Aaron. 2000. "The Cause of 1997-98 Asian Economcis Crisis : A Review of The Academic Literature and Comparison Between Indonesia and South Korea". Degree of MSc International Business at the Departement of Management, Birkbeck, University of London.

Ratna, Paula. 2017. "Malaysia's and Indonesia's Recovery From The Asia Financial Crisis Comparasio and Causes Behind The Recovery". Helsinki Metropolia University of Apllied Sciences, Bachelor Of Business, Europan Business Administration, Thesis,

Raz, Arisyi F., Tamarind P.K.I., Dea K.A., dan Syalindra C. 2012. Krisis Keuangan Global dan Pertumbuhan Ekonomi : Analisa Dari Perekonomian Asia Timur. Jakarta : 6th Annual Workshop Bulletin of Monetary Economics and Banking.

Rodrik, Dani. 2013. "Structural Change, Fundamentals, and Growth: An Overview". Institute For Advanced Study.
Sargento, Ana L.M. 2009. "Introducing InputOutput Analysis At The Regional Level : Basic Notions and Specific Issues". The Regional Economics Application Laboratory (REAL) 09-T-4 July 2009.

Siswanto, Ristya Paraisuda. 2010. Analisis Perubahan Struktur Ekonomi (Economic Landscape) Indonesia Sebelum, Saat, dan Setelah Krisis Ekonomi : Analisis Input-Output. Skripsi. Universitas Airlangga.

Sonis, Michael and Geoferey J.D. Hewings. 1999. "Economic Landcapes : Multiplier Product Matrix Analysis For Multiregional Input-Output Systems". Hitotsubashi Journal of Economics 40 (1999), pp. 59-74

Szirmai, Adam. 2012. "Industrialisation As An Engine Of Growth In Developing Countries, 1950-2005". Structural Change and Economic Dynamic 23 (2012) 406-420.

Tajerin. 2008. Perubahan Struktur Keterkaitan Sektor Perikanan Dalam Perekonomian Indonesia : Analisis Multiplier Product Matrix (MPM), Menggunakan Soni's Technique. Jurnal Bijak dan Riset Soial Ekonomi Kelautan dan Perikanan Vol.3 No.12008.

Tarmidi, Lepi T. 1999. Krisis Moneter Indonesia : Sebab, Dampak, Peran IMF dan Saran. Buletin Ekonomi Moeneter Perbankan.

Taylor, Lance and Codrina Rada. 2006. "Structural Change, Economic Policy, and Development". Nordic Journal of Political Economy Volume 32 Pages 51-71.

The World Bank.

Yustika, Ahmad Erani. 2012. "Economic Reform and Weak of the Institutional Change in Indonesia". International Journal of Humanities and Social Science Vol. 2 (20 